\title{
An Examination of the Impact of Rent Control on Mobile Home Prices in California
}

\author{
By \\ Diehang Zheng, Yongheng Deng, Peter Gordon, and David Dale-Johnson ${ }^{\dagger}$ \\ Lusk Center for Real Estate \\ University of Southern California \\ Los Angeles, CA 90089-0626
}

September, 2006

\begin{abstract}
This study examines the impact of rent control of mobile home parks in seven counties of California between 1983 and 2003. We assembled an extensive and timely data set and, thus, were able to test more carefully specified econometric models than had been employed in prior studies of California mobile-home rent control. We find that the nature of the rent control regime differentially impacts mobile home prices: the imposition of rigid rent control, rent control without vacancy decontrol, leads to higher growth rates in resale prices. While a flexible regime, or rent control with vacancy decontrol, results in lower growth rates in resale prices. This is consistent with economic theory, suggesting that the imposition of rigid rent control will lead to the capitalization of future rent savings when a coach is sold. That is, the buyer will not only pay for the coach but also for the net present value of the expected savings associated with the future legally constrained pad rent obligations to the landlord.
\end{abstract}

$\dagger$ The authors are grateful for helpful comments from John Quigley, and participants at the International Conference for Real Estates and the Macroeconomy at Beijing, Hoyt Fellows Research Seminar at the Homer Hoyt Institute, and the Western Regional Science Association Annual Conference at Santa Fe. The authors also gratefully acknowledge the Pacific Legal Foundation for providing the mobile home data and the financial support from the Lusk Center for Real Estate at USC for this study. 


\section{Introduction}

This study uses a unique micro-level mobile home transactions data set to analyze the impact of mobile home rent control in California. Is so doing, we hope to advance our understanding of the impact of price controls.

The social and economic impacts as well as the legal implications of price controls in the rental housing market have been debated extensively among economists and legal scholars. There appears to be widespread agreement on a number of points. Most economists agree that "a ceiling on rents reduces the quantity and quality of housing available" (Alston, Kearl, and Vaughan, 1992). ${ }^{1}$ While some renters benefit from lower rents, there are also costs (Olsen, 1972). ${ }^{2}$ Severe rent controls can cause undersupply in the apartment rental markets, and increase the search costs for tenants (Arnott and Igarashi, 2000). Below-market prices, if enforced, create opportunities for non-price rationing. Potential renters are obliged to invest time and effort chasing down access to the limited supply. These resource expenditures do not accrue to any sellers and cannot be converted to product and thus become a "deadweight" efficiency loss.

Also, maintenance of the existing housing stock and investment in new stock are expected to decline. In fact, abandonment of housing stock by owners has been observed. Housing conversions and demolitions have also been attributed to rent controls, an outcome further reducing the housing stock. Additional efficiency losses come from renters failing to adjust their housing consumption even though their circumstances change so they can hold on to their rent controlled units. (See Gyourko and Linneman, 1988, and Glaeser and Luttmer, 2003, for a thorough discussion of such effects for the case of New York city.) In addition, higher-income households are likely have an advantage in tracking valuable information on available units. Thus, equity gains from rent controls have seldom been realized by those most in need such benefit, suggesting that rent control has not been a policy useful for lower-income households

\footnotetext{
1 Alston, Kearl, and Vaughan (1992) reported that from their survey of a stratified random sample of 1,350 economists employed in the United States, more than three-quarters of the respondents agreed with the above statement.

2 One seminal study of rent control in New York City estimated that the costs to property owners are two times the benefits to renters (Olsen, 1972).
} 
that seek affordable housing (Quigley, 2002). For many reasons, then, rent controls preclude land and housing markets from doing what they are supposed to do, namely allocate scarce resources to their highest and best uses in light of ever changing wants, opportunities and constraints. Some existing studies found that a well-designed rent control regime could improve the unrestricted equilibrium of an imperfect market (Arnott, 1995). Rent control is preferred when the market distortion is the unavailability of insurance against a sharp, unanticipated rent rise. However, economists disagree on the net social effect of rent controls, for example, whether rent controls might affect increased homelessness by reducing the supply of rental units (Tucker, 1989, Quigley, 1990, HUD, 1991, Early and Olsen, 1998).

Rent control policies have caught the attention of legal scholars and have been extensively litigated. Legal scholars have debated whether some rent control regulations have violated the Fifth Amendment's Takings Clause. In Yee v. City of Escondido, Cal. (90-1947), 503 U.S. 519 (1992), the Supreme Court affirmed a Superior Court decision rejecting the argument that the ordinance effected a physical taking by depriving park owners of all use and occupancy of their property and granting to their tenants, and their tenants' successors, the right to physically permanently occupy and use the property. The Supreme Court ruled that the argument that rent control ordinances benefit current but not future property owners has "nothing to do with whether it causes a physical taking." Since then, some legal scholars have nevertheless argued that certain rent controls constitute a regulatory taking because the regulation has unfairly singled out some property owners to bear a burden that should be borne by the public at-large. (See Rubinfeld, 1992, and Radford, 2004, for a discussion.)

A unique aspect of the mobile home industry is the separate ownership of the coach and the pad where the coach is located; i.e., the mobile homeowner owns only the coach unit and rents a pad in a mobile home park on which she parks her (not-so-mobile) home. If the rent of the pad is constrained to be below market rents, coach owners are hypothesized to be able to sell the coach for more than it would be worth without rent control, thereby capitalizing the rent savings arising 
from rent control. The framework of separate ownership of coach unit and pad provides a unique opportunity to explicitly test the economic impact of rent control policy.

Several studies by Hirsch (1988), Hirsch et al (1988) and Hirsch and Rufolo (1999) have analyzed capitalization of the effects of rent control on coach unit values. Using straightforward hedonic modeling techniques and relatively small samples, the authors demonstrated that the savings from pad rent controls are capitalized.

In this study, we propose an extended economic model using a large sample of about 200,000 mobile home transaction records from January 1983 to May 2003 from seven counties in California. ${ }^{3}$ The coach transaction records include information on each coach's quality (brand, length, and width), age, address, original sale price, last sale price, last sale date, etc.

The purpose of this study is twofold. First, we intend to provide a more explicit and comprehensive measure of the economic impacts of rent controls through an analysis of micro transactions data. Second, we seek to provide evidence on the extent to which mobile home rent control constitutes a regulatory taking.

The remainder of this paper is organized as follows: Section two summarizes the unique characteristics of the mobile home market and rent controls in such markets. Section three describes our methodology for measuring rent control capitalization. Section four discusses the data; Section five presents our empirical results. The last section offers concluding remarks.

\section{The Mobile Home Industry}

In 2003, almost 9 million of the nation's 121 million housing units were mobile homes. This was 7.4 percent of the housing stock, up from 6.5 percent of the housing stock in 1987. Of the more than 338 thousand mobile homes added to the U.S. housing stock in 1999, more than 10 percent were added in the western states. As the number of Americans living in mobile homes increases, more attention is being paid to mobile home parks, their management and associated

\footnotetext{
3 The data are maintained by the California Department of Housing and Community Development (HCD).
} 
public policies. Among the issues of great interest are the effects of various types of mobile home rent control.

The imposition of rent controls in many California jurisdictions has been shown to explain declining shipments of mobile homes to California (Hirsch and Rufolo, 1999). More up-to-date time series transactions data for California also show that from 1983-2003 (through the month of May), the number of mobile homes subject to rent controls increased. Figures 1a through 1c show the transaction data in our sample by various mobile home descriptors including Total Traded Square Feet, Total Traded Value (constant dollars), and the Number of Transactions.

Rent control policies and by-laws vary in scope and severity. Flexible rent control regimes allow vacancy decontrol while more rigid regimes permit rent increases tied to one of a variety of cost-of-living indices. Rent control regulations in many cities have gone through cycles of control and decontrol, in some cases resulting in various vintages of the stock being grandfathered. A visible result is that some cities have neighborhoods with well-kept free-market rental housing adjacent to poorly maintained rent controlled housing.

Rent control systems are most well known for having been imposed on traditional multi-family rental housing units where the landlord owns the land and the building and rents individual units to tenants using formal or informal leasing arrangements. Legal systems have evolved to define the property rights of landlords and tenants. Rent controlled systems often "piggy-back" on these systems as security of tenure is deemed critical if landlords are permitted to increase rents when a unit is vacated. ${ }^{4}$

In contrast, in mobile home parks, the site ("pad") is rented to the tenant who either acquires the mobile home from a prior tenant or buys a new mobile home which is then assembled on-site. The curious distinction from the more common rent control of multi-family apartment units is that in a mobile home park the landlord owns the land (the pad) and the tenant owns the improvements (the coach). If there is no vacancy decontrol (ability on the part of the landlord to

\footnotetext{
${ }^{4}$ In more rigid rent control systems, controls are tied to the unit rather than the tenant.
} 
adjust the pad rent to the market rent when the coach is sold), the net present value of the anticipated future rent savings should be capitalized into the sales price of the coach if it stays in place. And usually it does as mobile homes are seldom moved once they are located on a pad. This unique aspect of rent control for mobile home parks has been the subject of some empirical analysis. Rent control systems for mobile home parks provide an opportunity to investigate the economic impact of the rent control policy on the tenants of mobile parks (i.e., the mobile coach owners).

Rapidly rising housing and land prices in California explain rising pad rents in many of the state's mobile home parks. As a consequence, renters in many jurisdictions responded by launching efforts to have rent controls enacted into law. In 2003, ninety seven California cities and eight counties had some sort of mobile home rent control.

In a series of papers published in the late 1980s, Hirsch and his colleagues (Hirsch, 1988, and Hirsch and Hirsch 1988) examined the impacts of rent controls on mobile homes in California. As alluded to previously, their analysis rests on the insight that ownership of mobile home living space is divided between the owner of the coach and the owner of the land, which is then leased to coach owners. Therefore, a coach atop a rent-controlled pad can be expected to sell at a premium. Hirsch et al's studies contain estimates of these values. Basing their analysis on a relatively small sample of observed transactions from the mid-1980s, they estimated that sales prices were boosted by 32 percent because of rent controls, other things equal.

An updated analysis by Hirsch and Rufolo (1999) focused on a single mobile home park in Oceanside, California. A hedonic regression based on a sample of 90 mobile home sales over the period 1986-1992 found that, other things equal, rent controls explain a price premium of eight percent.

More recently, Quigley (2002) presented an economic analysis of mobile home rent control based on a single mobile home park in San Rafael, California. The study documented the arms-length sales of 40 mobile homes in that park during a three-year period. The study estimated 
the average value of the rent control premium varied from $\$ 16$ to $\$ 160,000$. Price premiums for coaches enjoying rent control benefits in this study averaged an impressive 366 percent.

\section{The Model}

This section lays out the methodology adopted to model the capitalization of rent control. The approach to measuring housing price appreciation has advanced as a consequence of work by Bailey, Muth and Nourse (1963), Case and Shiller (1989), Case and Quigley (1992) and Harding, Rosenthal and Sirmans (2005) among others. In this paper, we employ repeat sales price indexes in the mobile home market in California to examine the impact of variation in rent control policies among jurisdictions, while controlling the socio-economics of the neighborhoods in question and of the physical attributes of the coaches themselves.

As discussed in previous sections, due to the separate ownership of the mobile home coach and the pad where the coach parks, coach owners in a jurisdiction with rigid rent control can capitalize the anticipated savings from controlled rents when they sell their units. Our model extends the work by Bailey, Muth and Nourse (1963) and Case and Shiller (1989) by decomposing the mobile home repeated sale house price differential into mobile home property value appreciation and the capitalization of the mobile home park rent control premium. ${ }^{5}$

Consider a mobile home coach which is observed to have been purchased and sold in periods $t$ and $t+\tau$, respectively. The purchase price is

$$
P_{t}=A \prod_{j} x_{j, t}^{\alpha_{j}} e^{y_{t}^{\prime} \beta} e^{z_{t}^{\prime} \delta} e^{\gamma_{t}}
$$

where $A$ is the parameter to capture the common factors' effect on all the units in the study; $x_{j, t}(j=1, \ldots, q)$ and $y_{t}$ are a set of property's hedonic characteristics observed at time $t ; z_{t}$ is a vector of binary regulatory features indicating different rent control regimes; $\alpha, \beta$ and $\delta$

\footnotetext{
${ }^{5}$ Our decomposition process is similar to the model proposed by Harding, Rosenthal and Sirmans (2005) in which they modify the repeated sales house price index model by decomposing the housing price appreciation into the components of capital depreciation and impact of housing maintenances.
} 
are shadow prices for hedonic characteristics, and regulatory features respectively; $\gamma_{t}$ is a vector of parameter for price index capturing aggregate price appreciation.

Let the price vary over time, from equation (1) the selling price at time $t+\tau$ will be

$$
P_{t+\tau}=A \prod_{j} x_{j, t+\tau}^{\alpha_{j}} e^{y_{t+\tau}^{\prime} \beta} e^{z_{t+\tau}^{\prime} \delta} e^{\gamma_{t+\tau}}
$$

From equations (1) and (2), the price ratio and the log price ratio, respectively, between $t+\tau$ and $t$ can be expressed as follows:

$$
\frac{P_{t+\tau}}{P_{t}}=\prod_{j}\left(\frac{x_{j, t+\tau}}{x_{j, t}}\right)^{\alpha_{j}} e^{\left(y_{t+\tau}-y_{t}\right)^{\prime} \beta} e^{\left(z_{t+\tau}-z_{t}\right)^{\prime} \delta} e^{\left(\gamma_{t+\tau}-\gamma_{t}\right)}
$$

and

$$
\ln \left(\frac{P_{t+\tau}}{P_{t}}\right)=\sum_{j} \alpha_{j}\left(\ln \left(x_{j, t+\tau}\right)-\ln \left(x_{j, t}\right)\right)+\left(y_{t+\tau}-y_{t}\right)^{\prime} \beta+\left(z_{t+\tau}-z_{t}\right)^{\prime} \delta+\left(\gamma_{t+\tau}-\gamma_{t}\right)
$$

If we assume the hedonic characteristics and regulatory attributes remain constant between the two transactions, i.e. $x_{j, t+\tau}=x_{j, t}, y_{t+\tau}=y_{t}$, and $z_{t+\tau}=z_{t}$, then equation (4) can be reduced to

$$
P_{t+\tau}=P_{t} e^{\left(\gamma_{t+\tau}-\gamma_{t}\right)}
$$

or the price change reflexes only the appreciation of market value of a constant quality property. This is exactly the repeat house price index model developed by Bailey, Muth and Nourse (1963) and Case and Shiller (1989).

Suppose the binary regulatory attributes between $t$ and $t+\tau$ change from $z$ to $z^{*}$, as a consequence of the adoption of a rent control ordinance during the time between the two transactions. The transacted price growth can be decomposed into constant quality property price appreciation and the impact of change in regulatory attributes.

$$
P_{t+\tau}=P_{t} e^{\left(\gamma_{t+\tau}-\gamma_{t}\right)} e^{\left(z^{*}-z\right)^{\prime} \delta}
$$


Let's assume the property price follows a log normal distribution ${ }^{6}$. We can test the above specifications by taking logarithms and rearranging equations (5) and (6), such that,

$$
\ln \left(\frac{P_{t+\tau}}{P_{t}}\right)=\gamma_{t+\tau}-\gamma_{t}+\varepsilon(\tau),
$$

and

$$
\ln \left(\frac{P_{t+\tau}}{P_{t}}\right)=\gamma_{t+\tau}-\gamma_{t}+\left(z^{*}-z\right)^{\prime} \delta+v(\tau),
$$

respectively, where $\varepsilon(\tau)$ and $v(\tau)$ are random error terms following a normal distribution with a diffusion variance which increases with the time span, $\tau$, between the two transactions.

For the case of mobile homes, provided all the other characteristics except for the rent control policy are time-invariant, the problem of selecting the proper specification of functional form or how qualitative and quantitative characteristics determine housing price growth has been eliminated. This elimination enhances the reliability of the estimates for the price index, $\gamma$.

For a sample of mobile homes that are transacted at various time periods, we obtain

$$
\ln \left(\frac{P_{t+\tau}}{P_{t}}\right)=D^{\prime} \gamma+\left(R C_{t+\tau}-R C_{t}\right)^{\prime} \delta+v(\tau),
$$

where $D$ is a vector of indicator variables taking values of $-1,0$, or 1 , determined by both purchase and sale of each property ${ }^{7} ; \gamma$ is price index vector; $\mathrm{RC}$ is a vector of indicator variables for various rent control regimes, ${ }^{8}$ and the modified repeated sales house price index model expressed in equation (9) allows us to decompose the capitalization of any rent control premium from property value appreciation.

Yet, Redfearn (2005) has pointed out an additional source of significant bias in aggregate indexes is the ignorance of local dynamics. Case and Quigley (1992) acknowledged that it is

\footnotetext{
6 The same assumption was implied by Bailey, Muth and Nourse (1963), Case and Shiller (1989), and Case and Quigley (1992).

7 The indicator variable takes value of -1 if the first transaction of the property occurs in period $t$; and takes value of 1 if the second transaction of the property occurs in period $t+\tau$; and takes value of 0 for all the other periods.

81 indicates the property is under rent control; 0 means no rent control policy adopted.
} 
appropriate to control statistically for the varying characteristics of properties in inferring price trends. Clapham et al. (2004) compared the stability of the repeat sales index and the hedonic index and found that character-based hedonic indexes appear to be substantially more stable than repeat-sales indexes. Hence we can modify equation (9) such that

$$
\begin{aligned}
\ln \left(\frac{P_{t+\tau}}{P_{t}}\right) & =D^{\prime} \gamma+\sum_{j} \alpha_{j}\left(\ln \left(x_{j, t+\tau}\right)-\ln \left(x_{j, t}\right)\right)+\left(y_{t+\tau}-y_{t}\right)^{\prime} \beta+\left(R C_{t+\tau}-R C_{t}\right)^{\prime} \delta+\mu(\tau) \\
& =D^{\prime} \gamma+Z^{\prime} \theta+\left(R C_{t+\tau}-R C_{t}\right)^{\prime} \delta+\mu(\tau),
\end{aligned}
$$

where $\theta$ is a vector of parameters which contains both $\alpha$ and $\beta ; Z$ (contains $x$ and $y$ ) is a vector of control variables capturing the location effect (measured by county), as well as hedonic effects (coach structure such as single-, double-, or triple-width, size, and neighborhood quality, etc.). This additional vector measures the proportional effects of location and the coach's amenities on the price growth rate.

\section{The Data}

In this research, twenty years of transactions data for mobile homes in seven counties of California (Los Angeles, Orange, Riverside, San Bernardino, San Diego, Santa Clara and Ventura) were made available to us. After geo-coding and matching with census tracts, there were 201,228 records from the period beginning of January 1983 and ending in May 2003. As we wished to create hybrid repeat-sale indexes, our focus is on sales of coaches for which there are two transactions, the first purchase and one resale, thus records for single sales were removed from the data set $^{9}$. Other records were eliminated because of incomplete city or mobile home park (Park ID) information. Outliers were also removed. ${ }^{10}$ These modifications left a 20 -year population of 137,221 sales in the data set.

\footnotetext{
9 For those properties with more than two transactions, only one resale record is included in the analysis.

${ }^{10}$ Records with incomplete geographic information and the top and bottom 1 percent of records based on the variables Original Sales Price (Constant 1996 dollar), Resale Price (Constant 1996 dollar), Size and Average Annual Growth
} 
Each record in the original data set is a mobile home transaction and includes the county, city, address, mobile home park name and ID, the original sale price for the new structure and resale price, the dates of sale (year, month, and day), and measures of other attributes of the unit such as model year, manufacturer, width, length, and type (single, double, or triple) and so on. These data were combined with census data by census tract, including median household income, changes in median household income, vacancy rate, proportion of the elderly ( $\geq 65$ years old), unemployment rate, and proportion of households with public assistance income, etc. We assume the census tract descriptors apply to the population living in mobile home parks. Finally, city-specific mobile home park rent control information was incorporated in the merged data set, including an indicator of the nature of the rent control regime. ${ }^{11}$ Table 1 defines each of the variables included in the data set.

There are 201 municipalities in the seven counties included in this study, among which 49 cities have a rent control ordinance. As many as 48,664 transactions in the data set (35.5 percent) were actually in jurisdictions where there was rent control. Among those, around half were under rigid rent control. From Figures 1a through 1c, we can see that the share of transactions as measured by square footage, value and number has increased significantly over the twenty-year period under study. Table 2 reveals in the right-hand column that the share of rent controlled units among the total mobile home transactions in the seven counties grew from almost thirteen percent in the early 1980 's to more than forty percent in 2003; moreover, the growth of those under rigid rent control outpaces the growth of transactions of units under flexible rent control since the middle 1990s. The change in the share of the square footage traded and the value traded attributable to rent-controlled units is of the same order. Table 3 presents the annual growth rates in rent-controlled units among the transactions as measured by square footage, value and number.

\footnotetext{
Rate were removed from the data set. We also explored the impact of focusing on properties where $0.5<$ (Constant Resale Price/Constant Original Sales Price) $<3.0$. We found that the results were robust to the imposition of this constraint. See Table 1 for descriptions of the variables.

${ }^{11}$ For cities with rent control, dummy variables were including starting in the quarter in which rent control was implemented. We also included a dummy variable that indicates whether or not there is vacancy decontrol. No vacancy decontrol reflects a more rigid rent control regime.
} 
The growth rates were $13.02,13.19$ and 13.17 percent, respectively. Clearly, rent control policies in the mobile home marketplace in California are taking on increasing importance.

Table 4 provides descriptive statistics for the continuous covariates for the complete data set as well as for each county. The original sale price varies from an average of $\$ 36,940$ (San Bernardino) to $\$ 46,410$ (Santa Clara); while the average resale price varies from $\$ 22,085$ (San Bernardino) to $\$ 54,441$ (Santa Clara). The average original sale price and resale price of the seven counties are $\$ 40,775$ and $\$ 34,118$ respectively. Mobile homes are less likely to keep up with rapid residential land market appreciation. Declines in the values of mobile homes are more common than for "stick-built" houses because the land component is often not part of the selling price. $^{12}$

Census tract variables including Median Household Income, Proportion of Households with Public Assistance Income, and Proportion of Persons $\geq 65$ Years Old were collected and also reported in Table 4. Other census tract-level variables, including Changes in Median Household Income, Vacancy Rate, and Unemployment Rate, were collected but were ultimately not of significance in the analysis so their summary statistics are not reported here.

Riverside county had the lowest median household income $(\$ 33,149)$ accompanied by the highest elderly population ( 24.4 percent). Santa Clara county was at the other extreme with the highest median household income $(\$ 52,492)$ and was tied with two other counties for the second lowest proportion of elderly population (11.4 percent). Perhaps surprisingly, Los Angeles county had the lowest proportion of elderly at 10.3 percent. San Bernardino and Riverside counties had the highest proportion of households benefiting from public assistance (9.0 and 8.6 percent, respectively) while Ventura and Orange counties had the lowest (5.0 and 5.2 percent, respectively).

We ultimately used the census information to segment the data set. Specifically, high- (or low-) income is defined by whether the census tract median household income is above (or

\footnotetext{
12 A more suitable comparable for mobile home sales would be sales of stick-built houses on leased land.
} 
below) the median census tract household income in the corresponding county. High- (or low-) elderly population proportion is defined by whether the census tract older population proportion is above (or below) the median census tract elderly population proportion in the corresponding county.

The smallest mobile homes are in San Bernardino and Los Angeles counties as measured by Unit's Size (1,093 and 1,094 square feet) while the largest are in Orange county (1,199 square feet). Ventura and San Diego counties have the oldest units (20.85 and 20.75 years, respectively) while Riverside county has the youngest (16.14 years).

Table 5 provides descriptive statistics for the sample's categorical covariates. Double-width mobile homes are the most common as indicated by a market share of almost 70 percent for the type "Double". The second biggest share is for single-width or the "Single" category at a market share of 26 percent; triple-width or the "Triple" category represent the luxury high-end mobile homes and have a five percent share of the market. The market share of double-width in Orange county is about 15 percentage points higher than in Los Angeles, while the market share of single-width is about 15 percentage points lower perhaps reflecting stage of the evolution of the mobile home market as well as the role of mobile homes as a housing choice when the homes were originally sold and the mobile home parks developed.

As noted earlier, a number of qualitative (“dummy”) variables were created which are critical to the analysis. First, communities are identified in which rent control of mobile home parks was present. Second, the policy is classified as rigid (by-laws which do not permit vacancy decontrol) or flexible (by-laws which permit vacancy decontrol), depending on whether or not vacancy decontrol is permitted. Then transactions within these jurisdictions were identified accordingly. Third, the first transaction after the adoption of a rent control policy is also indicated. The results of these classifications for the aggregate data set also appear in Table 5.

The prevalence of rent control ordinances varies dramatically among the seven counties. While in the aggregate, less than five percent of the transactions in Orange county were in 
rent-controlled parks, 82.7 percent of the transactions in Ventura county were in rent-controlled parks. As noted earlier, there was significant variation in these percentages between 1983 and 2003 with an increasing number and share of mobile home units being regulated by rent control policies over time. Of the 35.5 percent of mobile home transactions in our data set that are within rent controlled jurisdictions, roughly half of them are in jurisdictions with flexible rent control regimes and the rest are in jurisdictions with rigid rent control regimes. ${ }^{13}$

\section{Empirical Results}

We had a much larger and more comprehensive sample available to us than was employed in Hirsch (1988), Hirsch et al $(1988,1999)$ or Quigley (2002). As noted, we focused on 137,221 observations collected from over twenty years of mobile home transactions between 1983 and the early part of 2003. The ultimate transaction data base included only repeat- or multiple-sales along with descriptive information about the coach. Each sale was geo-coded permitting the census tract variables including Median Household Income (constant 1996 dollar), Proportion of Households with Public Assistance Income and Proportion of Persons $\geq 65$ Years Old to be appended to each record. The first two are proxies for local amenity values as well as demand, while the third is a proxy for one of the components of demand for mobile home units -- as many older households choose mobile homes as a cost-effective housing choice in retirement.

Our working hypothesis was that because rigid rent control policies allow coach owners to pass on future pad rent savings to subsequent owners of the coach, prices of coaches in these communities will increase more rapidly or decrease less rapidly than the prices of coaches in communities without rent control or flexible rent control. To be sure, this is actually a net effect. Buyers value protections from rent increases but also may be wary of owning property in cities

\footnotetext{
${ }^{13}$ Rent control regimes may become less rigid or more rigid through time as policies evolve due to the changing economic and political environment. We were able to identify regimes which are currently rigid (no vacancy decontrol permitted) or flexible (vacancy decontrol permitted). In order to ascertain whether today's regime accurately reflected the nature of the regime since 1983, we surveyed every city in our data set (201). We received 55 responses in total with 20 of them from cities with rent control in place. The results of the survey supported the approach taken. We inferred that the results of the survey could be extrapolated to the full sample.
} 
with governments that have shown themselves to be ready to place limits on property rights. This suggests that any weak form of rent control could be associated with especially ambiguous expectations. It is not clear which effect would dominate.

Thus, if rent control or the rigidity of the rent control regime influences the rate of change of coach prices, the relevant estimated coefficient will be positive and significant. Moreover, the biggest beneficiary is the first generation of mobile home owners when the rent control policy is/was adopted. For the standard case, the following coach owners are not able to realize a comparable benefit because they have paid for most of the premium for rent control upfront. Nevertheless, in cases when future appreciation had been underestimated, there would be additional rents to be further capitalized in the later transactions.

Table 6 presents the results of GLS estimation of equations (9) and (10). ${ }^{14}$ In model (1), mobile homes values are positively influenced if rigid rent control policies are adopted but those will decrease when flexible rent control policies are adopted. This set of relationships still holds when the proportional effects of other hedonic factors have been considered in model (2). Riverside and San Bernardino have the lowest growth rates, while Ventura outperforms all the other counties. The larger luxury units experience higher appreciation than smaller ones. The coaches in the neighborhoods with a higher proportion of households with public assistance suffer from lower growth rates. For rent control policies, the first generation mobile home owners under rent control benefit from the adoption of rigid rent control ordinances (rent control without vacancy decontrol), but they experience a net loss, ceteris paribus, from flexible rent control (rent control with vacancy decontrol), as suggested may be possible in our theoretical discussion.

\footnotetext{
${ }^{14}$ We adopt GLS estimation approach to address the problem of heterogeneity due to the diffusion process of the error terms specified in equations (9) and (10). Following Case and Shiller (1989) and Deng, Quigley and Van Order (2000), we first estimate equations (9) and (10) by OLS. In the second stage, we estimate a diffusion process of the variance by regressing the square term of residuals, $\varepsilon^{2}$, collected from the first stage OLS regression on a quadratic function of time span between the two sales, such that $\varepsilon(\tau)^{2}=\beta_{1} \tau+\beta_{2} \tau^{2}+\omega$, where $\tau$ is the duration between original sale and resale (measured in quarters), and $\omega$ is a normally distributed error term. In the third stage we re-estimate the mobile home price index model using a GLS estimation approach weighted by the square root of the estimated diffusion variance, $\hat{\varepsilon}(\tau)$, obtained from the second stage.
} 
Our results also show that for the following generations of tenants, rigid rent control policy is no longer a significant factor in determining the resale price, while a flexible rent control regime may continue contributing to lower resale price.

Because rigid rent control practically freezes real rents paid, in a market where demand increases in the long run such as in the market for mobile homes, the longer this restriction is in force, the bigger would be the price gap, between the controlled units and the uncontrolled units. Model (3) replaces the simple dummy variable "adoption of rent control without vacancy decontrol" by the interactive variable "adoption of rent control without vacancy decontrol $\times$ number of years under rent control at time of transaction". The interactive variable is significant and keeps the same sign as its simple dummy counterpart in model (2). It shows that the adoption of rigid rent control will push up the mobile home value by 1.5 percent per year till the first transaction after the introduction of the policy. Also, because of different rent control adoption schedules, San Diego and Santa Clara have different signs for their dummy variables in this model compared to model (2).

Figure 2a provides the plot of dependent variable, Log (resale price/original price) or Log-Ratio, for different counties. Santa Clara has the highest growth rate and the lowest variance; Riverside has the lowest growth rate with the greatest variance. Hence, it is inappropriate to treat the seven counties equally at the aggregate level.

Similarly, Figure $2 \mathrm{~b}$ and $2 \mathrm{c}$ give the plots of Log-Ratio for different structure groups (single, double, and triple), and for different rent control groups. Due to the difference among the subgroups a proportional model as in Equation (10) is adopted.

From a policy perspective it might be valuable to know which income-age group can benefit the most from a rent control policy, and also, who might suffer the most. Figure $3 \mathrm{a}$ and $3 \mathrm{~b}$ present the plots of Log-Ratio by different median household income census tracts and different proportion of elderly population census tracts. The differences between higher and lower income communities, as well as older and younger communities are visible. Hence, we refine the full 
sample and re-estimate the index with proportional location and hedonic factors for each income/age group, in order to estimate rent control's impact under different scenarios.

The re-estimated results for different median household income census tract groups are presented in Table 7a. Adoption of rigid rent control leads to higher increase in resale price for coaches in wealthier communities, but homeowners in poorer communities suffer less from the adoption of flexible rent control. Moreover, the future homeowners in wealthier neighborhoods can still enjoy the benefit from rigid rent control to a lesser extent.

Table $7 \mathrm{~b}$ provides the estimates for census tracts with higher and lower proportions of elderly population. Mobile home owners in neighborhoods with younger populations benefit from the adoption of rigid rent control ordinances more than in the neighborhoods with elderly populations, while the latter suffer less from new flexible rent control policies. Clearly, younger mobile home owners have a longer anticipated benefit period. The following generations of mobile home owners in older neighborhoods are relatively better off from both rigid and flexible rent control ordinances and slightly better off under the former.

In Table 7c, we show the results for further refined subsamples by both median household income and proportion of elderly population at the census tract level. When we consider income and age at the same time, age is a higher order factor than income: both younger communities, with higher or lower income, enjoy greater benefit from the adoption of rigid rent control than the older communities. Homeowners in younger communities with higher median household income are the biggest beneficiaries, while the ones in older communities with lower median household income experience the lowest benefits. For the newly adopted flexible rent control policies, homeowners in older communities with higher median household income might be the only beneficiaries, and all the rest will suffer, especially the ones in younger communities with higher median income. The future homeowners in the former community will continue benefiting from rigid rent control but to a lesser extent. 
Finally, Figure $4 \mathrm{~b}$ presents the simulated comparison of indexes between units in the jurisdictions without rent control and units in hypothetical jurisdictions which adopted rigid rent control in the beginning of 1993. The price index of the latter diverges from the former soon after the adoption of the policy. In Tables $9 \mathrm{a}, \mathrm{b}, \mathrm{c}$ and $\mathrm{d}$, we report results for an average mobile home in Los Angeles, we find that if the unit was under a flexible rent control regime before the original purchase, its real growth rate in price would be 1.7 percentage points less than comparable units in a market without rent control or units under a rigid rent control regime. In contrast with an unchanged rent control policy environment, the adoption of rent control between the first and second transactions leads to a greater and more significant change in prices. More rigid rent control leads to a growth rate of 13.6 percentage points more than the units in a market without rent control, or an increase in coach value of $\$ 8,081$. In contrast, flexible rent control results in a growth rate 8.8 percentage points lower than the coaches in a market without rent control, or a loss in value of $\$ 1,088$.

\section{Conclusions}

Mobile homes are usually owned by households that pay a periodic rent for use of the land in a mobile home park (a pad) on which the coach is located. Because mobile homes tend not to be mobile but rather fixed on the pad on which they are initially located, and since the pads are rented, economic theory suggests that the imposition of rent control will lead to the capitalization of future rent savings when a coach is sold. That is, the buyer will not only pay for the coach but also for the net present value of the expected savings associated with the constrained future pad rent obligations to the landlord.

Our results support the hypothesis, based on a more extensive and timely data set than had been employed in similar prior studies in California. Results from our extensive analysis suggest that higher income groups receive a relatively larger first time rigid rent control premium (adoption of rigid rent control increases the coach value by 18.6 percent for higher income groups 
and 12.5 percent for lower income groups, respectively), but also have to face greater losses from the adoption of flexible rent control (coach value decrease by 11 percent for higher income groups and 5 percent for lower income groups). Younger owners on average can get about a 24.8 percent premium for adoption of rigid rent control while elderly owners on average benefit from an 8.6 percent premium which is 18 percentage points lower than the former. On the other hand, the elderly owners are able to gain from the adoption of flexible rent control policies through a 6.6 percent increase in their coach value, while the younger owners suffer a 3.4 percent decrease. When we combine the two factors of income and age, higher income younger owners are the biggest winners from the adoption of rigid rent control which brings them a roughly 34 percent increase in coach value. In contrast, lower income elderly owners on average benefit the least from rigid rent control with a 7 percent increase in coach value. Higher income elderly owners also benefit from rigid rent control with a 16 percent increase in coach values.

We hope to have contributed to the rent control discussion by estimating the size and incidence of its impacts as well as how they vary with the strictness of the controls. This is a controversial policy area and we hope that our estimated effects based on a much larger sample than had heretofore been available as well as the use of more rigorous and detailed methods enhance the quality of the debate. 


\section{References}

Alston, Richard M., J. R. Kearl, and Michael B. Vaughan, 1992, "Is There a Consensus among Economists in the 1990's?" American Economic Review, 82, 203-209.

Arnott, Richard, 1995, "Time for Revisionism on Rent Control?" The Journal of Economic Perspectives, 9:1, 99-120.

Arnott, Richard and Masahiro Igarashi, 2000, "Rent Control, Mismatch Costs and Search Efficiency," Regional Science and Urban Economics, 30, 249-288.

Arnott, Richard, 1998, "Rent Control," The New Palgrave Dictionary of Economics and the Law, New York: MacMillan and Co.

Bailey, Martin J., Richard F. Muth, and Hugh O. Nourse, 1963, "A Regression Model for Real Estate Price Index Construction," Journal of the American Statistical Association, 58, 933-942.

Basu, Kaushik and Patrick M. Emerson, 2000, "The Economics and Law of Rent Control," Economic Journal, 110, 939-962.

Case, Bradford and John M. Quigley, 1991, "The Dynamics of Real Estate Prices," The Review of Economics and Statistics, 93:1, 50-58.

Case, Karl E. and Robert J. Shiller, 1989, "The Efficiency of the Market for Single Family Homes," American Economic Review, 79:1, 125-37.

Caudill, Steven B., Richard W. Ault, and Richard P. Saba, 1989, "Efficient Estimation of the Costs of Rent Controls," The Review of Economics and statistics, 71:1, 154-159.

Clapham, Eric, Peter Englund, John M. Quigley, and Christian L. Redfearn, 2004, "Revisiting the Past: Revision in Repeat Sales and Hedonic Indexes of House Prices", unpublished working paper.

Deng, Yongheng, John M. Quigley, and Robert Van Order, 2000, "Mortgage Terminations, Heterogeneity and the Exercise of Mortgage Options," Econometrica, 68, 275-307.

Early, Dirk W. and Edgar O. Olsen, 1998, "Rent Control and Homeless," Regional Science and Urban Economics, 28, 797-816.

Early, Dirk W., 1999, "Rent Control, Rental Housing Supply, and the Distribution of Tenant Benefits," Journal or Urban Economics, 48,185-204.

Epple, Dennis, 1998, "Rent Control with Reputation: Theory and Evidence," Regional Science and Urban Economics, 28, 679-710.

Fallis, George and Lawrence B. Smith, 1984, "Uncontrolled Prices in a Controlled Market: The Case of Rent Control," The American Economic Review, 74:1, 193-200.

Glaeser, Edwrd L., 1996, "The Social Costs of Rent Control Revisited," National Bureau of Economic Research Working Paper 5441.

Glaeser, Edward L. and Erzo F.P. Luttmer, 2003, "The Misallocation of Housing Under Rent Control", The American Economic Review, 93:4, 1027-1046.

Gyourko, Joseph and Linneman, Peter, 1989, "Equity and Efficiency Aspects of Rent Control: An Empirical Study of New York City," Journal of Urban Economics, 26:1, 54-74.

Harding, John P., Stuart S. Rosenthal, and D.F. Sirmans, 2005, "Depreciation of Housing Capital, Maintenance, and the Gains from Homeownership Estimates From a Repeat Sales Model," unpublished working paper.

Hill, R. Carter, J.R. Knight, and C.F. Sirmans, 1997, "Estimating Capital Asset Price Indexes," 
The Review of Economics and Statistics, 79:2, 226-233.

Hirsch, Werner Z., 1988, “An Inquiry into Effects of Mobile Home Park Rent Control,” Journal of Urban Economics, 24, 212-226.

Hirsch, Werner Z. and Joel G. Hirsch, 1988, "Legal-Economic Analysis of Rent Controls in A Mobile Home Context: Placement Values and Vacancy Decontrol," UCLA Law Review, 35, 399-467.

Hirsch, Werner Z. and Anthony M. Rufolo, 1999, "The Regulation of Immobile Housing Assets under Divided Ownership," International Review of Law and Economics, 19, 383-397.

Johnson, D. Gale, 1951, "Rent Control and the Distribution of Income", The American Economic Review, 41:2, 569-582.

Malpezzi, Stephen, 1998, "Welfare Analysis of Rent Control with Side Payments: A Natural Experiment in Cairo, Egypt," Regional Science and Urban Economics, 28, 773-795.

Mason, Carl and John M. Quigley, 2004, "The Curious Institution of Mobile Home Rent Control: A Case Study of Mobile Home Parks in California," unpublished working paper.

Moon, Choon-Geol and Janet G. Stotsky, 1993, "The Effect of Rent Control on Housing Quality Change: A Longitudinal Analysis," The Journal of Political Economy, 101:6, 1114-1148.

Murray, Michael P., C. Peter Rydell, C. Lance Barnett, Carol E. Hillestad, and Kevin Neels, 1991, "Analyzing Rent Control: The Case of Los Angeles," Economic Inquiry, 29, 601-625.

Nagy, J., 1997, “Do Vacancy Decontrol Provisions Undo Rent Control?” Journal of Urban Economics, 42, 64-78.

Olsen, Edgar O., 1972, "An Econometric analysis of Rent Control", The Journal of Political Economy, 80:6, 1081-1100.

Palmquist, Raymond B., 1980, "Alternative Techniques for Developing Real Estate Price Indexes," The Review of Economics and Statistics, 62: 3, 442-448.

Quigley, John M., 1990, "Does Rent Control Cause Homeless? Taking the Claim Seriously," Journal of Policy Analysis and Management, 9, 89-93.

Quigley, John M., 2002, "Economic Analysis of Mobile Home Rent Control: The Example of San Rafael, California," unpublished working paper.

Radford, R. S. 2004, “Why Rent Control Is Still a Regulatory Taking?” unpublished working paper.

Rapaport, Carol, 1992, "Rent Regulation and Housing Market Dynamics," The American Economic Review, 82:2, 446-451.

Redfearn, Christian L., 2005, "Measure Globally, Aggregate Locally: The Interplay of Housing Market Dynamics and Price Index Construction", unpublished working paper.

Rubinfeld, Daniel L., 1992, "Regulatory Takings: The Case of Mobile Home Rent Control," Chicago-Kent Review, 67(3), 923-929.

Tucker, W., 1989, “America's Homeless: Victims of Rent Control," Heritage Foundation Backgrounder, 685.

Turner, Bengt and Stephen Malpezzi, 2003, "A Review of Empirical Evidence on the Costs and Benefits of Rent Control," Swedish Economic Policy Review, 10, 11-56.

US Department of Housing and Urban Development (HUD), 1991, Report to Congress on Rent Control. Office of Policy Development and Research. 
Table 1. Definitions of Variables

\begin{tabular}{ll}
\hline \hline ADDRESS & Address \\
CITY & Located city \\
COUNTY & Located county \\
PARKNAME & Mobile home park name \\
PARKID & Mobile home park ID \\
MDLYR & Model Year \\
MFG & Manufacturer \\
TRADE & Trade \\
W1/L1 & W1/L1 single wide/length \\
W2/L2 & W1W2/L1L2 double wide/length \\
W3/L3 & W1W2W3/L1L2L3 triple wide/length \\
LEGAL & Legal owner \\
SOLD & Sold date (year, month, day) \\
ORIG & Original sale price (current dollar) \\
CONORIG & Original sale price (constant 1996 dollar) \\
RESALE & Resale price (current dollar) \\
CONRESALE & Resale price (constant 1996 dollar) \\
TYPE & Type of the unit (single, double, triple) \\
SIZE & Total size of the unit (square footage) \\
WELFARE & Proportion of households with public assistance income, census tract \\
MDHHY & Median household income (current dollar) census tract \\
OLD & Proportion of persons $\geq 65$ years old, census tract \\
RENT CONTROL & Dummy variable (1: with RC; 0: without RC) \\
DECON & Dummy variable (1: RC with vacancy decontrol) \\
NODEC & Dummy variable (1: RC without vacancy decontrol) \\
\hline \hline
\end{tabular}


Table 2a. Time Varying Mobile Home Transaction Statistics

\begin{tabular}{|c|c|c|c|c|c|c|c|}
\hline \multirow[b]{2}{*}{ Year } & \multicolumn{7}{|c|}{ Total units traded (square footage, in thousands) } \\
\hline & All & $\begin{array}{c}\text { Rent } \\
\text { control } \\
\text { group }\end{array}$ & $\begin{array}{c}\text { Rent } \\
\text { control with } \\
\text { vacancy } \\
\text { decontrol }\end{array}$ & $\begin{array}{l}\text { Rent control } \\
\text { without } \\
\text { vacancy } \\
\text { decontrol }\end{array}$ & $\begin{array}{l}\text { Percentage } \\
\text { of rent } \\
\text { control } \\
\text { group }(\%)\end{array}$ & $\begin{array}{l}\text { Percentage of rent } \\
\text { control with } \\
\text { vacancy decontrol } \\
\text { group }(\%)\end{array}$ & $\begin{array}{l}\text { Percentage of rent } \\
\text { control without } \\
\text { vacancy decontrol } \\
\text { group (\%) }\end{array}$ \\
\hline 1983 & 3780.61 & 549.43 & 235.73 & 313.69 & 14.53 & 6.24 & 8.30 \\
\hline 1984 & 4692.13 & 793.32 & 403.75 & 389.57 & 16.91 & 8.60 & 8.30 \\
\hline 1985 & 5338.81 & 1017.03 & 537.97 & 479.05 & 19.05 & 10.08 & 8.97 \\
\hline 1986 & 5660.14 & 1169.70 & 659.36 & 510.34 & 20.67 & 11.65 & 9.02 \\
\hline 1987 & 6159.30 & 1327.07 & 755.21 & 571.87 & 21.55 & 12.26 & 9.28 \\
\hline 1988 & 6908.11 & 1708.47 & 955.21 & 753.26 & 24.73 & 13.83 & 10.90 \\
\hline 1989 & 7668.03 & 2259.03 & 1360.25 & 898.78 & 29.46 & 17.74 & 11.72 \\
\hline 1990 & 6747.48 & 2230.17 & 1353.02 & 877.15 & 33.05 & 20.05 & 13.00 \\
\hline 1991 & 5545.80 & 1980.36 & 1212.42 & 767.93 & 35.71 & 21.86 & 13.85 \\
\hline 1992 & 5588.80 & 2027.33 & 1204.14 & 823.18 & 36.27 & 21.55 & 14.73 \\
\hline 1993 & 6533.61 & 2840.45 & 1554.55 & 1285.91 & 43.47 & 23.79 & 19.68 \\
\hline 1994 & 7749.34 & 3650.92 & 1948.21 & 1702.72 & 47.11 & 25.14 & 21.97 \\
\hline 1995 & 8438.82 & 4036.33 & 2013.67 & 2022.66 & 47.83 & 23.86 & 23.97 \\
\hline 1996 & 7859.52 & 3427.39 & 1484.17 & 1943.22 & 43.61 & 18.88 & 24.72 \\
\hline 1997 & 8421.09 & 3610.09 & 1557.90 & 2052.20 & 42.87 & 18.50 & 24.37 \\
\hline 1998 & 9880.72 & 4042.02 & 1668.37 & 2373.65 & 40.91 & 16.89 & 24.02 \\
\hline 1999 & 10559.00 & 4098.66 & 1846.78 & 2251.88 & 38.82 & 17.49 & 21.33 \\
\hline 2000 & 10742.12 & 4444.57 & 1856.43 & 2588.13 & 41.38 & 17.28 & 24.09 \\
\hline 2001 & 11350.12 & 4675.10 & 2134.15 & 2540.96 & 41.19 & 18.80 & 22.39 \\
\hline 2002 & 11713.24 & 4629.11 & 1959.71 & 2669.40 & 39.52 & 16.73 & 22.79 \\
\hline $2003 *$ & 3330.66 & 1339.89 & 645.71 & 694.19 & 40.23 & 19.39 & 20.84 \\
\hline
\end{tabular}

* First five months of year 2003. 
Table 2b. Time Varying Mobile Home Transaction Statistics (Con.)

\begin{tabular}{|c|c|c|c|c|c|c|c|}
\hline \multirow[b]{2}{*}{ Year } & \multicolumn{7}{|c|}{ Total traded value (constant 1996 dollar, in millions) } \\
\hline & All & $\begin{array}{l}\text { Rent } \\
\text { control } \\
\text { group }\end{array}$ & $\begin{array}{c}\text { Rent control } \\
\text { with vacancy } \\
\text { decontrol }\end{array}$ & $\begin{array}{c}\text { Rent control } \\
\text { without } \\
\text { vacancy } \\
\text { decontrol } \\
\end{array}$ & $\begin{array}{l}\text { Percentage } \\
\text { of rent } \\
\text { control } \\
\text { group }(\%) \\
\end{array}$ & $\begin{array}{l}\text { Percentage of rent } \\
\text { control with } \\
\text { vacancy decontrol } \\
\text { group }(\%)\end{array}$ & $\begin{array}{l}\text { Percentage of rent } \\
\text { control without } \\
\text { vacancy decontrol } \\
\text { group (\%) } \\
\end{array}$ \\
\hline 1983 & 149.15 & 20.47 & 8.25 & 12.22 & 13.73 & 5.53 & 8.19 \\
\hline 1984 & 187.08 & 30.60 & 14.57 & 16.03 & 16.36 & 7.79 & 8.57 \\
\hline 1985 & 214.95 & 38.27 & 18.81 & 19.47 & 17.81 & 8.75 & 9.06 \\
\hline 1986 & 228.32 & 44.81 & 23.35 & 21.46 & 19.63 & 10.23 & 9.40 \\
\hline 1987 & 248.29 & 51.68 & 27.23 & 24.45 & 20.82 & 10.97 & 9.85 \\
\hline 1988 & 282.15 & 65.51 & 33.84 & 31.67 & 23.22 & 11.99 & 11.22 \\
\hline 1989 & 316.37 & 87.19 & 48.03 & 39.16 & 27.56 & 15.18 & 12.38 \\
\hline 1990 & 263.64 & 81.85 & 46.54 & 35.30 & 31.05 & 17.65 & 13.39 \\
\hline 1991 & 187.68 & 62.05 & 35.87 & 26.18 & 33.06 & 19.11 & 13.95 \\
\hline 1992 & 156.79 & 52.20 & 29.36 & 22.84 & 33.30 & 18.73 & 14.57 \\
\hline 1993 & 141.68 & 60.83 & 31.11 & 29.73 & 42.94 & 21.96 & 20.98 \\
\hline 1994 & 143.31 & 70.03 & 32.69 & 37.34 & 48.87 & 22.81 & 26.06 \\
\hline 1995 & 146.08 & 71.54 & 30.04 & 41.50 & 48.97 & 20.56 & 28.41 \\
\hline 1996 & 144.17 & 65.65 & 24.06 & 41.59 & 45.54 & 16.69 & 28.85 \\
\hline 1997 & 172.45 & 80.86 & 29.87 & 50.99 & 46.89 & 17.32 & 29.57 \\
\hline 1998 & 226.68 & 98.28 & 33.82 & 64.46 & 43.36 & 14.92 & 28.44 \\
\hline 1999 & 264.58 & 105.92 & 41.79 & 64.13 & 40.03 & 15.79 & 24.24 \\
\hline 2000 & 330.46 & 148.97 & 46.57 & 102.40 & 45.08 & 14.09 & 30.99 \\
\hline 2001 & 358.56 & 153.78 & 56.01 & 97.77 & 42.89 & 15.62 & 27.27 \\
\hline 2002 & 402.18 & 166.20 & 58.98 & 107.22 & 41.32 & 14.67 & 26.66 \\
\hline $2003 *$ & 117.17 & 48.09 & 20.51 & 27.58 & 41.04 & 17.51 & 23.54 \\
\hline
\end{tabular}

* First five months of year 2003. 
Table 2c. Time Varying Mobile Home Transaction Statistics (Con.)

\begin{tabular}{cccccccc}
\hline \hline & \multicolumn{7}{c}{ Number of units transacted } \\
\cline { 2 - 7 } & & $\begin{array}{c}\text { Rent } \\
\text { control } \\
\text { group }\end{array}$ & $\begin{array}{c}\text { Rent control } \\
\text { with vacancy } \\
\text { decontrol }\end{array}$ & $\begin{array}{c}\text { Rent control } \\
\text { without } \\
\text { vacancy } \\
\text { decontrol }\end{array}$ & $\begin{array}{c}\text { Percentage } \\
\text { of rent } \\
\text { control } \\
\text { group (\%) }\end{array}$ & $\begin{array}{c}\text { Percentage of rent } \\
\text { control with } \\
\text { vacancy decontrol } \\
\text { group (\%) }\end{array}$ & $\begin{array}{c}\text { Percentage of rent } \\
\text { control without } \\
\text { vacancy decontrol } \\
\text { group (\%) }\end{array}$ \\
\hline 1983 & 3452 & 455 & 198 & 257 & 13.18 & 5.74 & 7.44 \\
1984 & 4311 & 671 & 351 & 320 & 15.56 & 8.14 & 7.42 \\
1985 & 4883 & 848 & 458 & 390 & 17.37 & 9.38 & 7.99 \\
1986 & 5167 & 974 & 568 & 406 & 18.85 & 10.99 & 7.86 \\
1987 & 5619 & 1128 & 652 & 476 & 20.07 & 11.60 & 10.47 \\
1988 & 6199 & 1460 & 828 & 632 & 23.55 & 13.36 & 10.66 \\
1989 & 6763 & 1918 & 1197 & 721 & 28.36 & 17.70 & 12.18 \\
1990 & 6050 & 1929 & 1192 & 737 & 31.88 & 19.70 & 13.43 \\
1991 & 5057 & 1760 & 1081 & 679 & 34.80 & 21.38 & 14.54 \\
1992 & 5150 & 1862 & 1113 & 749 & 36.16 & 21.61 & 19.28 \\
1993 & 5929 & 2562 & 1419 & 1143 & 43.21 & 23.93 & 21.44 \\
1994 & 6918 & 3221 & 1738 & 1483 & 46.56 & 25.12 & 23.37 \\
1995 & 7517 & 3558 & 1801 & 1757 & 47.33 & 23.96 & 24.19 \\
1996 & 6974 & 3016 & 1329 & 1687 & 43.25 & 19.06 & 23.77 \\
1997 & 7481 & 3190 & 1412 & 1778 & 42.64 & 18.87 & 23.83 \\
1998 & 8702 & 3583 & 1509 & 2074 & 41.17 & 17.34 & 20.89 \\
1999 & 9195 & 3584 & 1663 & 1921 & 38.98 & 18.09 & 21.87 \\
2000 & 9225 & 3802 & 1657 & 2145 & 41.21 & 17.96 & 22.39 \\
2001 & 9815 & 4036 & 1889 & 2147 & 41.12 & 19.25 & 20.67 \\
2002 & 10013 & 3974 & 1732 & 2242 & 39.69 & 17.30 & 19.78 \\
$2003 *$ & 2801 & 1133 & 554 & 579 & 40.45 & & \\
\hline \hline
\end{tabular}

* First five months of year 2003. 
Table 3. Annual Growth Rates (1984-2002)

\begin{tabular}{|c|c|c|c|c|c|c|c|c|c|c|c|c|}
\hline \multirow[b]{2}{*}{ Year } & \multicolumn{4}{|c|}{ Total units traded (square footage) } & \multicolumn{4}{|c|}{ Total traded value (constant 1996 dollar) } & \multicolumn{4}{|c|}{ Number of units transacted } \\
\hline & All & $\begin{array}{l}\text { Rent } \\
\text { control } \\
\text { group }\end{array}$ & $\begin{array}{l}\text { Rent control } \\
\text { with vacancy } \\
\text { decontrol }\end{array}$ & $\begin{array}{c}\text { Rent control } \\
\text { without } \\
\text { vacancy } \\
\text { decontrol }\end{array}$ & All & $\begin{array}{l}\text { Rent } \\
\text { control } \\
\text { group }\end{array}$ & $\begin{array}{l}\text { Rent control } \\
\text { with vacancy } \\
\text { decontrol }\end{array}$ & $\begin{array}{c}\text { Rent control } \\
\text { without } \\
\text { vacancy } \\
\text { decontrol }\end{array}$ & All & $\begin{array}{l}\text { Rent } \\
\text { control } \\
\text { group }\end{array}$ & $\begin{array}{l}\text { Rent control } \\
\text { with vacancy } \\
\text { decontrol }\end{array}$ & $\begin{array}{c}\text { Rent control } \\
\text { without } \\
\text { vacancy } \\
\text { decontrol }\end{array}$ \\
\hline 1984 & $24.11 \%$ & $44.39 \%$ & $71.27 \%$ & $24.19 \%$ & $25.43 \%$ & $49.46 \%$ & $76.55 \%$ & $31.17 \%$ & $24.88 \%$ & $47.47 \%$ & $77.27 \%$ & $24.51 \%$ \\
\hline 1985 & $13.78 \%$ & $28.20 \%$ & $33.25 \%$ & $22.97 \%$ & $14.89 \%$ & $25.09 \%$ & $29.07 \%$ & $21.47 \%$ & $13.27 \%$ & $26.38 \%$ & $30.48 \%$ & $21.88 \%$ \\
\hline 1986 & $6.02 \%$ & $15.01 \%$ & $22.56 \%$ & $6.53 \%$ & $6.22 \%$ & $17.08 \%$ & $24.15 \%$ & $10.25 \%$ & $5.82 \%$ & $14.86 \%$ & $24.02 \%$ & $4.10 \%$ \\
\hline 1987 & $8.82 \%$ & $13.45 \%$ & $14.54 \%$ & $12.06 \%$ & $8.75 \%$ & $15.34 \%$ & $16.62 \%$ & $13.95 \%$ & $8.75 \%$ & $15.81 \%$ & $14.79 \%$ & $17.24 \%$ \\
\hline 1988 & $12.16 \%$ & $28.74 \%$ & $26.48 \%$ & $31.72 \%$ & $13.64 \%$ & $26.75 \%$ & $24.29 \%$ & $29.50 \%$ & $10.32 \%$ & $29.43 \%$ & $26.99 \%$ & $32.77 \%$ \\
\hline 1989 & $11.00 \%$ & $32.23 \%$ & $42.40 \%$ & $19.32 \%$ & $12.13 \%$ & $33.10 \%$ & $41.92 \%$ & $23.66 \%$ & $9.10 \%$ & $31.37 \%$ & $44.57 \%$ & $14.08 \%$ \\
\hline 1990 & $-12.01 \%$ & $-1.28 \%$ & $-0.53 \%$ & $-2.41 \%$ & $-16.67 \%$ & $-6.13 \%$ & $-3.09 \%$ & $-9.85 \%$ & $-10.54 \%$ & $0.57 \%$ & $-0.42 \%$ & $2.22 \%$ \\
\hline 1991 & $-17.81 \%$ & $-11.20 \%$ & $-10.39 \%$ & $-12.45 \%$ & $-28.81 \%$ & $-24.19 \%$ & $-22.93 \%$ & $-25.84 \%$ & $-16.41 \%$ & $-8.76 \%$ & $-9.31 \%$ & $-7.87 \%$ \\
\hline 1992 & $0.78 \%$ & $2.37 \%$ & $-0.68 \%$ & $7.20 \%$ & $-16.46 \%$ & $-15.87 \%$ & $-18.15 \%$ & $-12.74 \%$ & $1.84 \%$ & $5.80 \%$ & $2.96 \%$ & $10.31 \%$ \\
\hline 1993 & $16.91 \%$ & $40.11 \%$ & $29.10 \%$ & $56.21 \%$ & $-9.64 \%$ & $16.53 \%$ & $5.94 \%$ & $30.13 \%$ & $15.13 \%$ & $37.59 \%$ & $27.49 \%$ & $52.60 \%$ \\
\hline 1994 & $18.61 \%$ & $28.53 \%$ & $25.32 \%$ & $32.41 \%$ & $1.15 \%$ & $15.13 \%$ & $5.10 \%$ & $25.61 \%$ & $16.68 \%$ & $25.72 \%$ & $22.48 \%$ & $29.75 \%$ \\
\hline 1995 & $8.90 \%$ & $10.56 \%$ & $3.36 \%$ & $18.79 \%$ & $1.93 \%$ & $2.15 \%$ & $-8.12 \%$ & $11.14 \%$ & $8.66 \%$ & $10.46 \%$ & $3.62 \%$ & $18.48 \%$ \\
\hline 1996 & $-6.86 \%$ & $-15.09 \%$ & $-26.30 \%$ & $-3.93 \%$ & $-1.31 \%$ & $-8.23 \%$ & $-19.90 \%$ & $0.22 \%$ & $-7.22 \%$ & $-15.23 \%$ & $-26.21 \%$ & $-3.98 \%$ \\
\hline 1997 & $7.15 \%$ & $5.33 \%$ & $4.97 \%$ & $5.61 \%$ & $19.61 \%$ & $23.17 \%$ & $24.15 \%$ & $22.60 \%$ & $7.27 \%$ & $5.77 \%$ & $6.25 \%$ & $5.39 \%$ \\
\hline 1998 & $17.33 \%$ & $11.96 \%$ & $7.09 \%$ & $15.66 \%$ & $31.45 \%$ & $21.54 \%$ & $13.19 \%$ & $26.43 \%$ & $16.32 \%$ & $12.32 \%$ & $6.87 \%$ & $16.65 \%$ \\
\hline 1999 & $6.86 \%$ & $1.40 \%$ & $10.69 \%$ & $-5.13 \%$ & $16.72 \%$ & $7.77 \%$ & $23.57 \%$ & $-0.52 \%$ & $5.67 \%$ & $0.03 \%$ & $10.21 \%$ & $-7.38 \%$ \\
\hline 2000 & $1.73 \%$ & $8.44 \%$ & $0.52 \%$ & $14.93 \%$ & $24.90 \%$ & $40.64 \%$ & $11.44 \%$ & $59.67 \%$ & $0.33 \%$ & $6.08 \%$ & $-0.36 \%$ & $11.66 \%$ \\
\hline 2001 & $5.66 \%$ & $5.19 \%$ & $14.96 \%$ & $-1.82 \%$ & $8.51 \%$ & $3.23 \%$ & $20.28 \%$ & $-4.52 \%$ & $6.40 \%$ & $6.15 \%$ & $14.00 \%$ & $0.09 \%$ \\
\hline 2002 & $3.20 \%$ & $-0.98 \%$ & $-8.17 \%$ & $5.05 \%$ & $12.16 \%$ & $8.07 \%$ & $5.30 \%$ & $9.66 \%$ & $2.02 \%$ & $-1.54 \%$ & $-8.31 \%$ & $4.42 \%$ \\
\hline $\begin{array}{l}\text { Average } \\
\text { annual } \\
\text { growth } \\
\text { rate }\end{array}$ & $6.65 \%$ & $13.02 \%$ & $13.71 \%$ & $13.00 \%$ & $6.56 \%$ & $13.19 \%$ & $13.13 \%$ & $13.79 \%$ & $6.22 \%$ & $13.17 \%$ & $14.07 \%$ & $13.00 \%$ \\
\hline
\end{tabular}




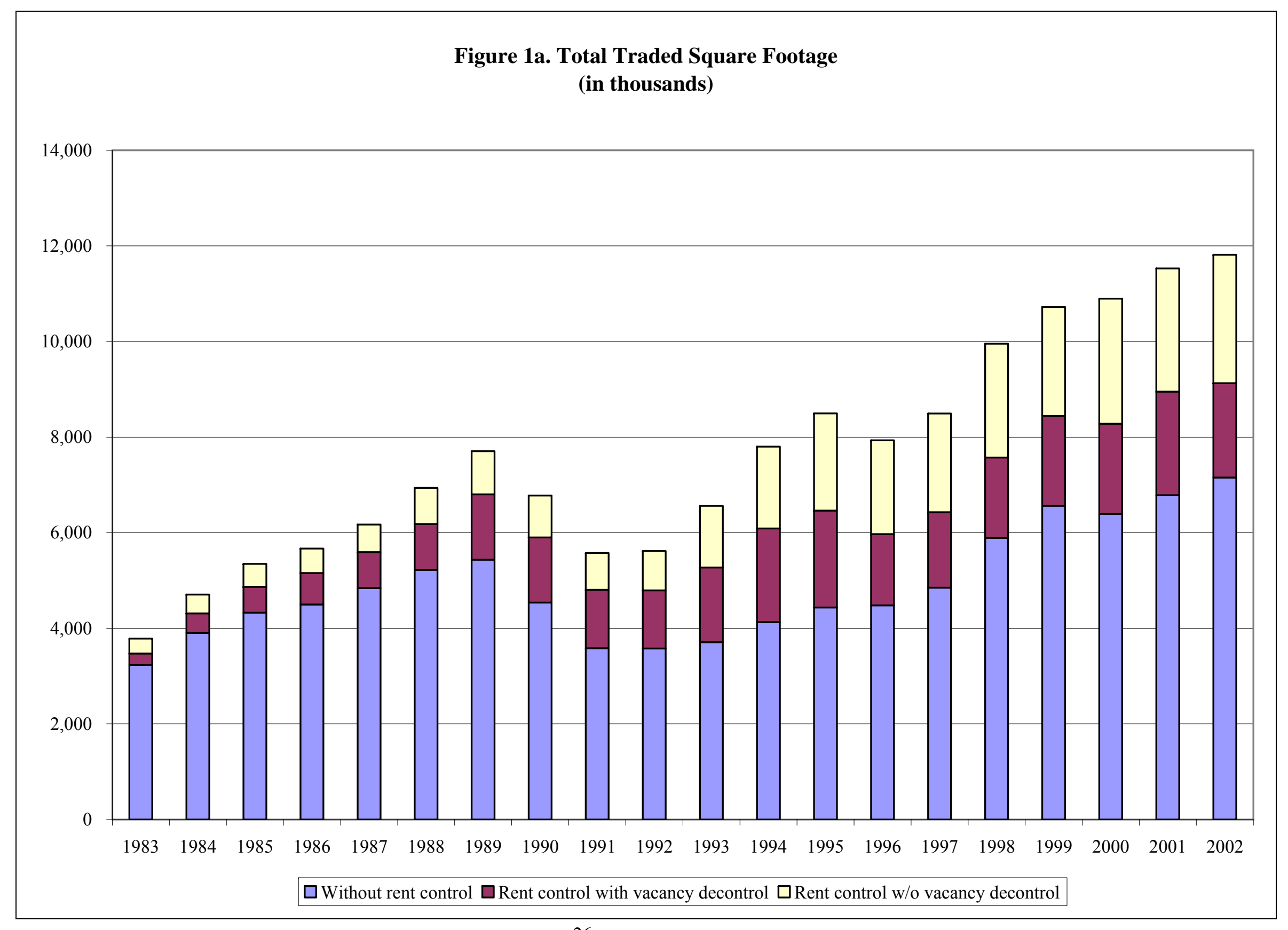




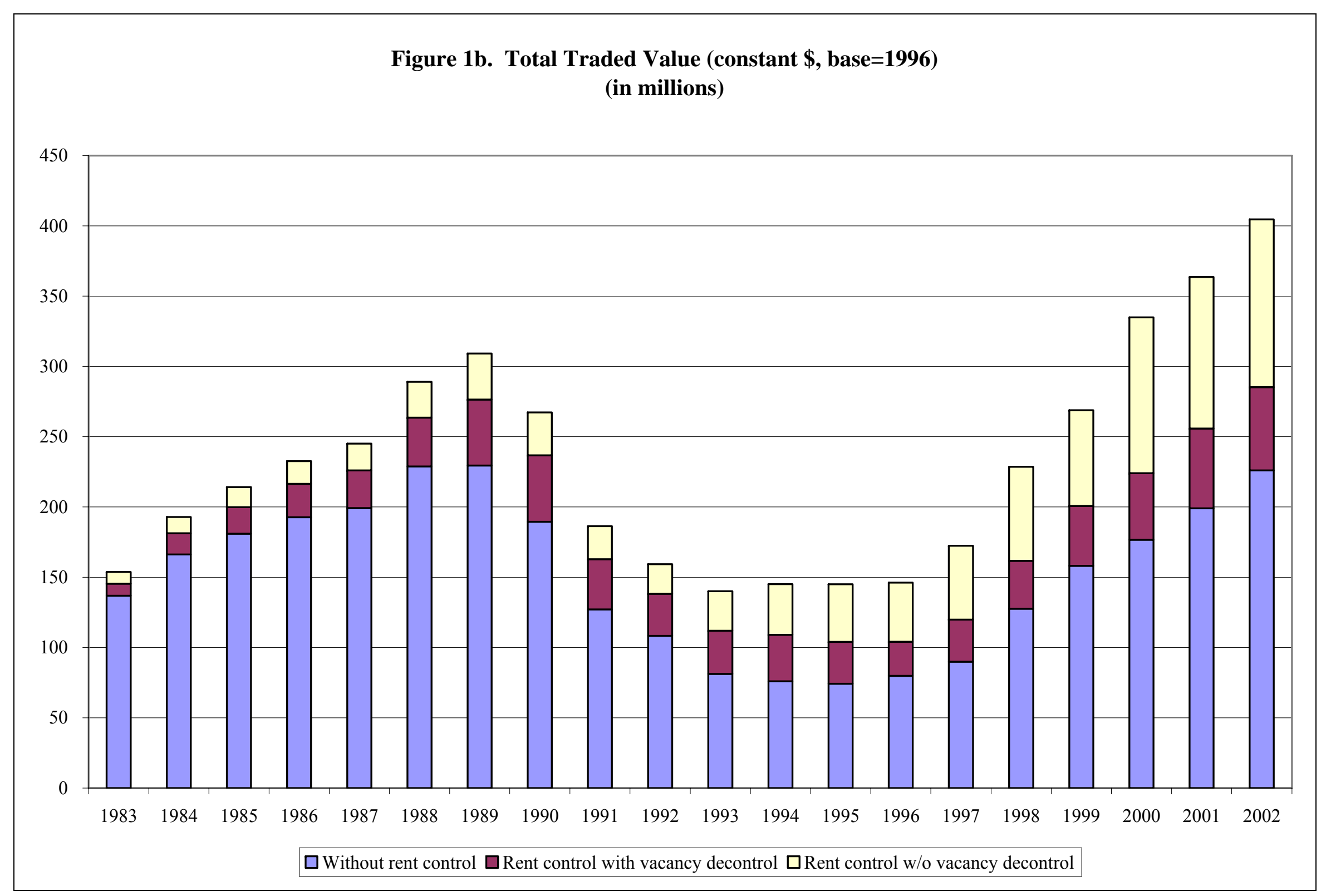




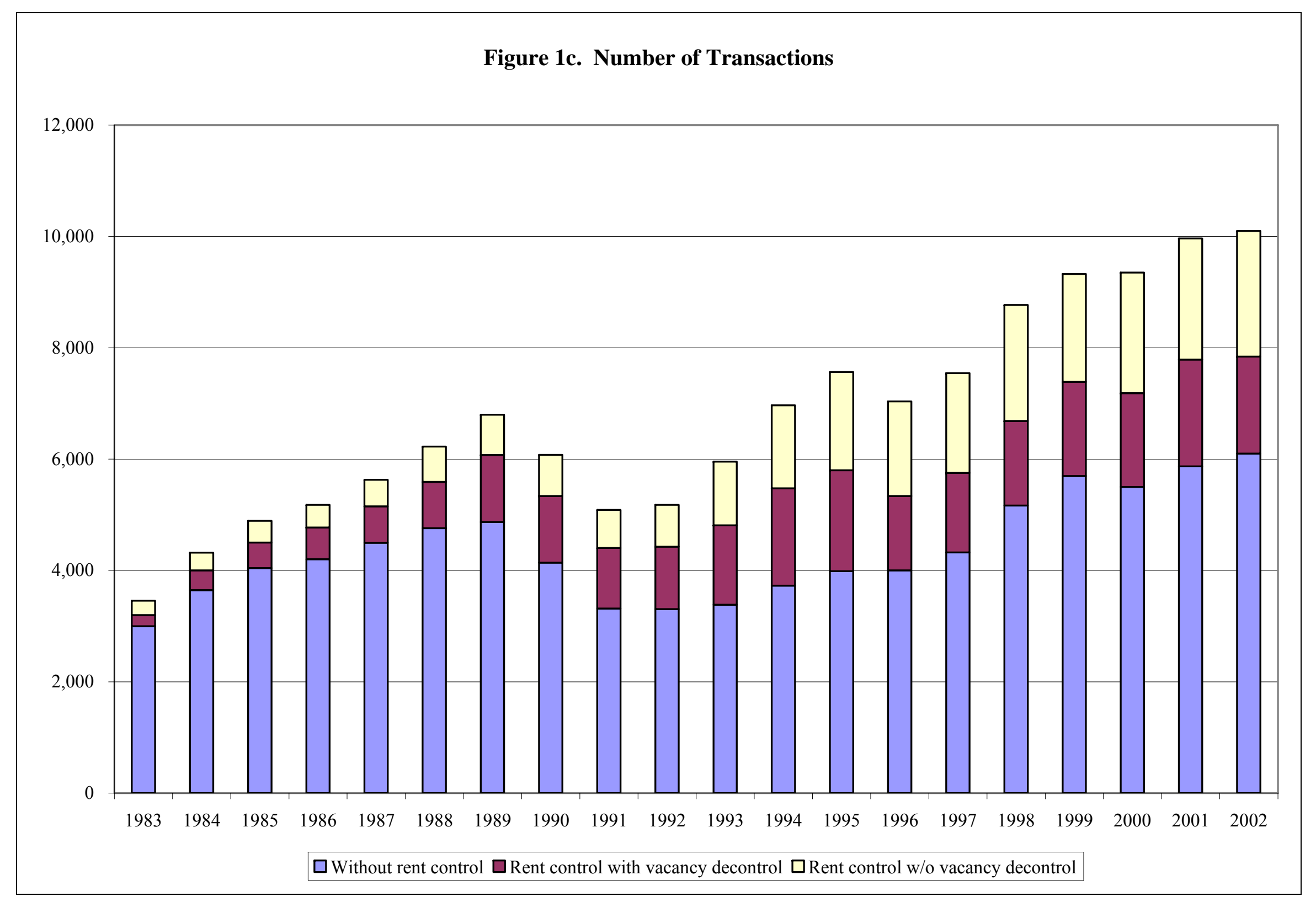


Table 4. Descriptive Statistics - means and standard deviations of continuous covariates

\begin{tabular}{|c|c|c|c|c|c|c|c|c|}
\hline & All & $\begin{array}{c}\text { Los } \\
\text { Angeles } \\
\end{array}$ & Orange & Riverside & $\begin{array}{c}\text { San } \\
\text { Bernardino }\end{array}$ & $\begin{array}{c}\text { San } \\
\text { Diego } \\
\end{array}$ & $\begin{array}{l}\text { Santa } \\
\text { Clara } \\
\end{array}$ & Ventura \\
\hline Original price (constant 1996 dollar) & $\begin{array}{c}40,775 \\
(21150)\end{array}$ & $\begin{array}{c}40,696 \\
(22183)\end{array}$ & $\begin{array}{l}45,362 \\
(21313)\end{array}$ & $\begin{array}{c}39,691 \\
(20029)\end{array}$ & $\begin{array}{c}36,940 \\
(18324)\end{array}$ & $\begin{array}{c}38,102 \\
(19407)\end{array}$ & $\begin{array}{c}46,410 \\
(25154)\end{array}$ & $\begin{array}{c}38,699 \\
(18691)\end{array}$ \\
\hline Resale price (constant 1996 dollar) & $\begin{array}{c}34,118 \\
(26201)\end{array}$ & $\begin{array}{c}33,207 \\
(24331)\end{array}$ & $\begin{array}{c}38,982 \\
(26981)\end{array}$ & $\begin{array}{c}28,567 \\
(25116)\end{array}$ & $\begin{array}{c}22,085 \\
(17834)\end{array}$ & $\begin{array}{c}30,925 \\
(22767)\end{array}$ & $\begin{array}{c}54,441 \\
(31546)\end{array}$ & $\begin{array}{c}42,687 \\
(28392)\end{array}$ \\
\hline Median household income (constant 1996 dollar) & $\begin{array}{c}43,274 \\
(13524)\end{array}$ & $\begin{array}{c}46,923 \\
(14011)\end{array}$ & $\begin{array}{c}47,193 \\
(12135)\end{array}$ & $\begin{array}{l}33,149 \\
(9862)\end{array}$ & $\begin{array}{l}36,650 \\
(11097)\end{array}$ & $\begin{array}{c}39,991 \\
(10462)\end{array}$ & $\begin{array}{c}52,492 \\
(15100)\end{array}$ & $\begin{array}{c}48,194 \\
(11262)\end{array}$ \\
\hline Proportion of households with public assistance income & $\begin{array}{c}0.067 \\
(0.047)\end{array}$ & $\begin{array}{c}0.070 \\
(0.046)\end{array}$ & $\begin{array}{c}0.052 \\
(0.039)\end{array}$ & $\begin{array}{c}0.086 \\
(0.040)\end{array}$ & $\begin{array}{c}0.090 \\
(0.053)\end{array}$ & $\begin{array}{c}0.059 \\
(0.045)\end{array}$ & $\begin{array}{c}0.057 \\
(0.044)\end{array}$ & $\begin{array}{c}0.050 \\
(0.033)\end{array}$ \\
\hline Proportion of persons $\geq 65$ years old & $\begin{array}{c}0.132 \\
(0.094)\end{array}$ & $\begin{array}{c}0.103 \\
(0.055)\end{array}$ & $\begin{array}{c}0.117 \\
(0.088)\end{array}$ & $\begin{array}{c}0.244 \\
(0.160)\end{array}$ & $\begin{array}{c}0.115 \\
(0.067)\end{array}$ & $\begin{array}{c}0.151 \\
(0.083)\end{array}$ & $\begin{array}{c}0.114 \\
(0.079)\end{array}$ & $\begin{array}{c}0.122 \\
(0.052)\end{array}$ \\
\hline Unit's size (sq. ft.) & $\begin{array}{l}1,127 \\
(396)\end{array}$ & $\begin{array}{l}1,094 \\
(411)\end{array}$ & $\begin{array}{l}1,199 \\
(370)\end{array}$ & $\begin{array}{l}1,160 \\
(422)\end{array}$ & $\begin{array}{l}1,093 \\
(383)\end{array}$ & $\begin{array}{l}1,103 \\
(389)\end{array}$ & $\begin{array}{l}1,158 \\
(406)\end{array}$ & $\begin{array}{l}1,113 \\
(376)\end{array}$ \\
\hline Unit's age & $\begin{array}{l}19.23 \\
(9.15)\end{array}$ & $\begin{array}{l}19.10 \\
(9.39)\end{array}$ & $\begin{array}{l}19.28 \\
(9.15)\end{array}$ & $\begin{array}{l}16.01 \\
(8.51)\end{array}$ & $\begin{array}{l}19.09 \\
(9.24)\end{array}$ & $\begin{array}{l}20.75 \\
(9.07)\end{array}$ & $\begin{array}{l}18.82 \\
(8.55)\end{array}$ & $\begin{array}{l}20.85 \\
(8.61)\end{array}$ \\
\hline Sample size & 137,221 & 31,404 & 23,934 & 12,912 & 20,827 & 28,551 & 13,423 & 6,170 \\
\hline
\end{tabular}

Note:

Standard deviations are in parenthesis. 
Table 5. Descriptive Statistics - frequencies of categorical covariates

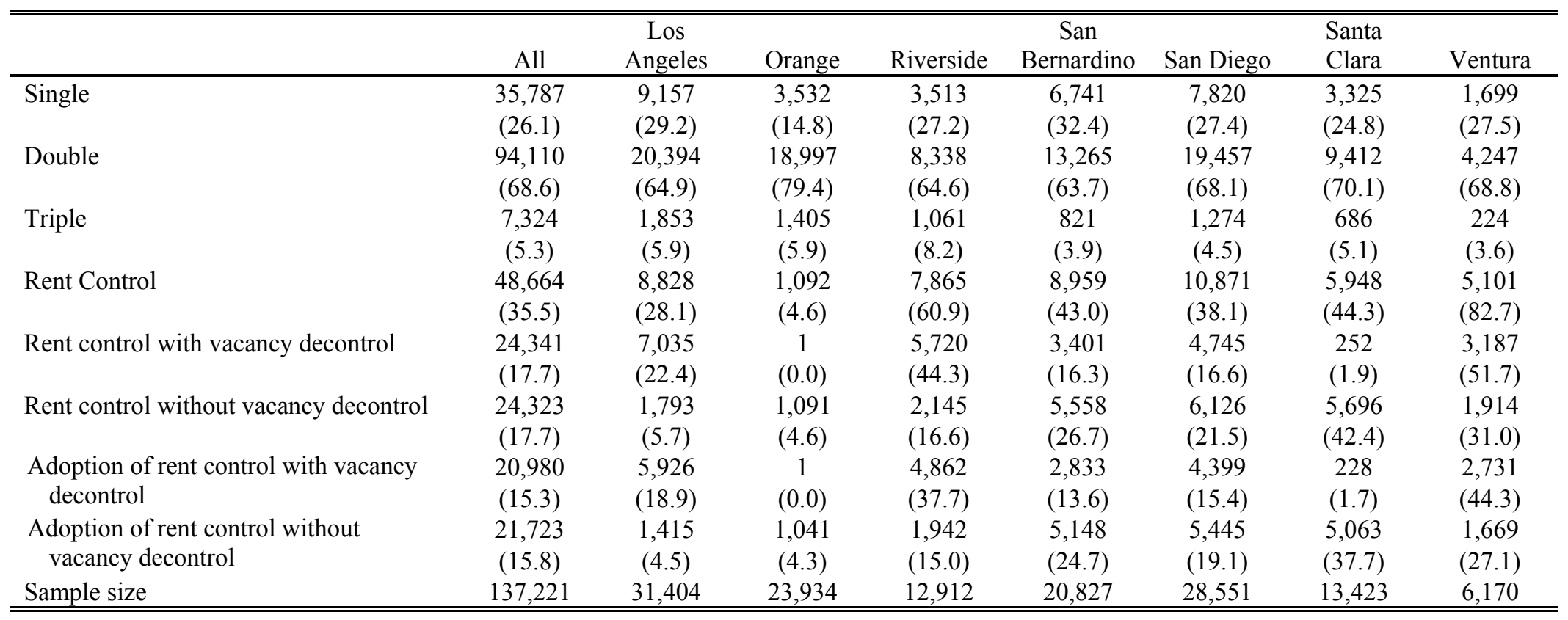

Note:

Percentages to corresponding full or county samples are in parenthesis. 
Figure 2. Logarithm of Price Growth Rate by Sub-Groups

These figures present the box plot of the logarithm of price growth rates by various sub-groups. The boxes contain the middle $50 \%$ of the data. The upper edges of the boxes indicate the $75^{\text {th }}$ percentile of the data set, and the lower edges indicate the $25^{\text {th }}$ percentile. The lines in the boxes indicate the median value of the data. The ends of the vertical lines indicate the minimum and maximum data values. The logarithm of price growth rate is defined as: $\ln \left(\frac{P_{t+\tau}}{P_{t}}\right)$, where $\ln (\bullet)$ is natural logarithm function, $P_{t+\tau}$ is the resale price after $\tau$ periods since the original sale at $t, P_{t}$ is the original sales price at $t$.

Figure 2a. Logarithm of Price Growth Rate by County

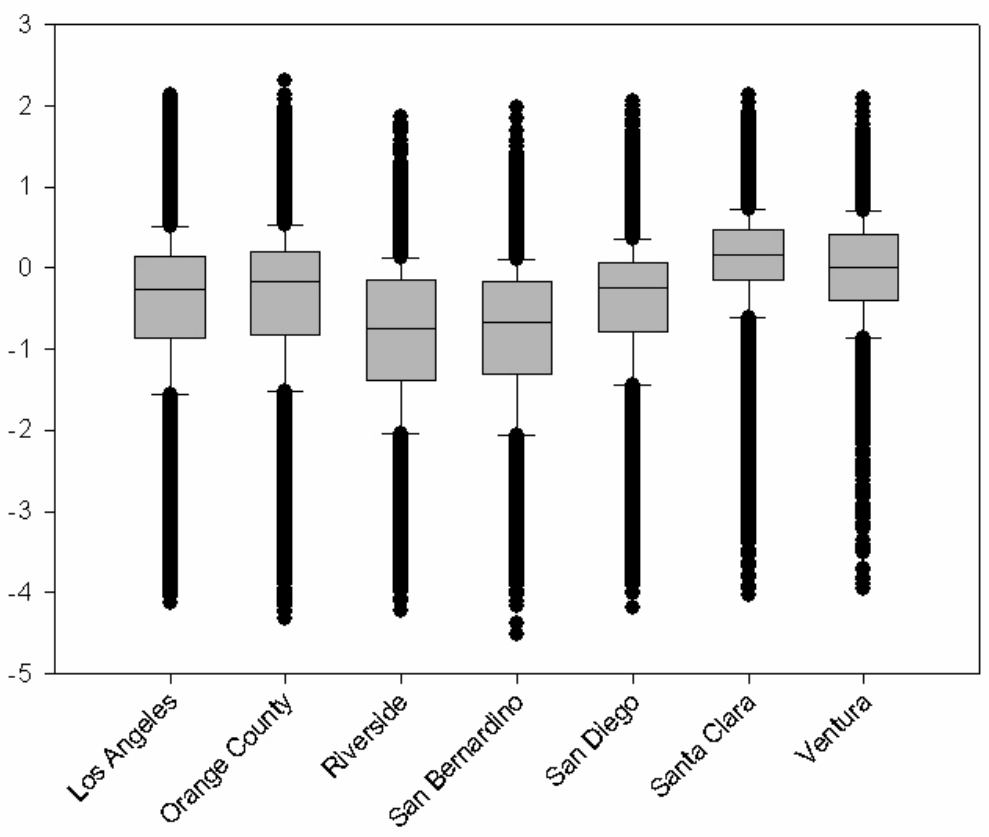


Figure 2b. Logarithm of Price Growth Rate by Coach Structure

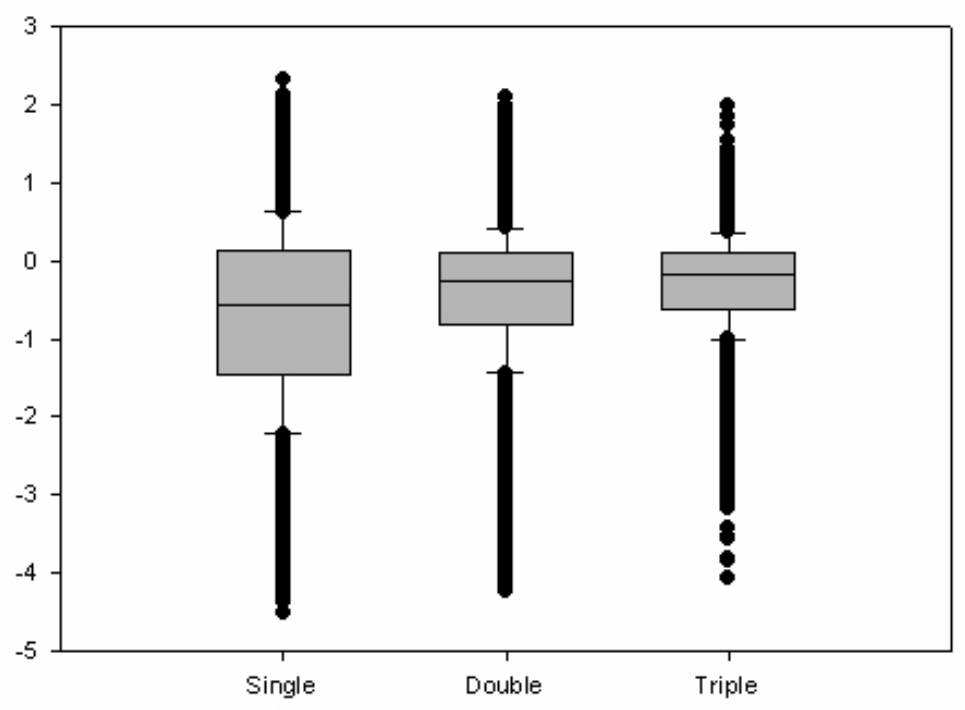

Figure 2c. Logarithm of Price Growth Rate by Rent Control Regime

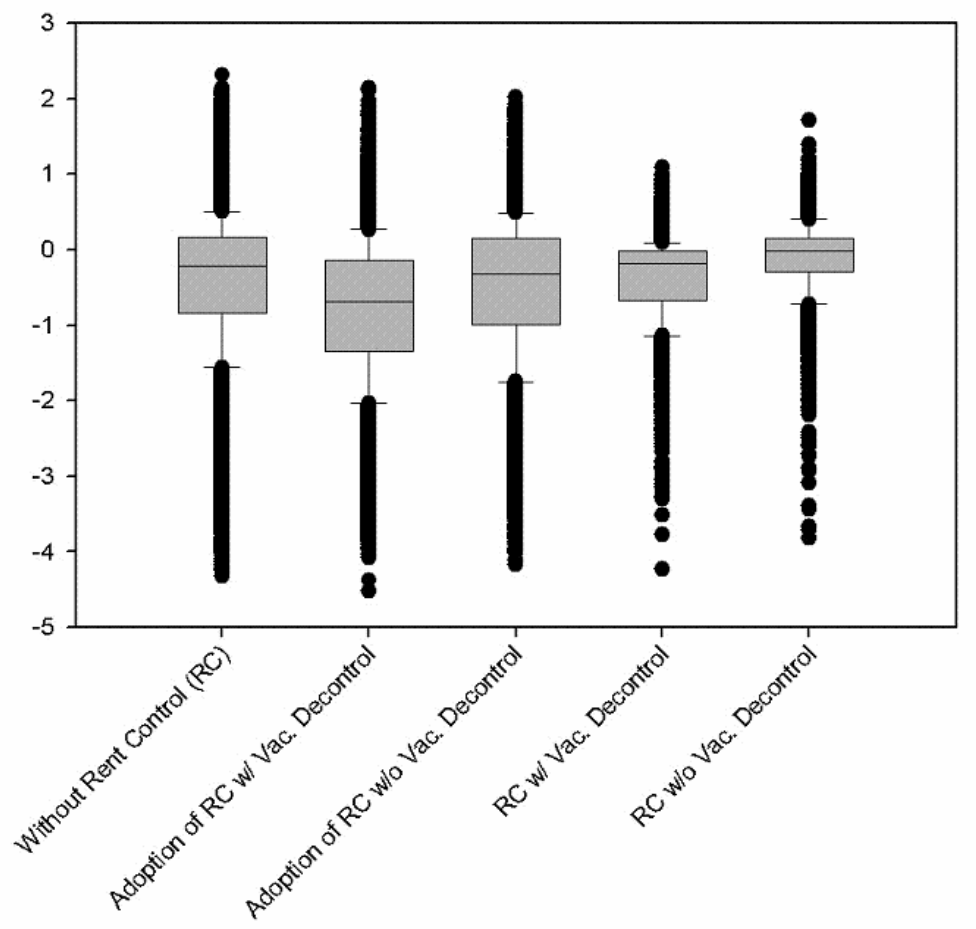


Table 6. GLS Estimates for Rent Control Impact on Mobile Home Price

The table reports rent control impacts on mobile home prices. We estimate the rent control impact by decomposing the capitalization of rent control premium from a repeated-sales mobile home price index model specified in equations (9) and (10) using a three-stage GLS estimation approach. In the first stage, we use OLS to estimate the following mobile home price index model which decomposes the rent control premium capitalization from the mobile home price appreciation: $\ln \left(\frac{P_{t+\tau}}{P_{t}}\right)=D^{\prime} \gamma+Z^{\prime} \theta+\left(R C_{t+\tau}-R C_{t}\right)^{\prime} \delta+\mu(\tau)$, where $\ln (\cdot)$ is natural logarithm function, $P_{t+\tau}$ is the resale price after $\tau$ periods since the original sale at $t, P_{t}$ is the original sales price at $t$, $D$ is a repeated-sales transaction vector composed of $-1,0$ and $1 ; R C$ is a vector of indicator variables to capture the rent control premium capitalization; $Z$ is a vector of hedonic characteristics capturing the location effect (measured by county), and coach structure characteristics, such as single, double, or triple-width, size, and neighborhood quality, etc., and $\mu$ is the normally distributed error term with a diffusion variance varying by the time span between two transactions. In the second stage, we estimate a diffusion process of the mobile home price index by regressing the square term of residuals, $\varepsilon^{2}$, collected from the first stage OLS regression on a quadratic function of time span between the two sales, such that, $\varepsilon(\tau)^{2}=\beta_{1} \tau+\beta_{2} \tau^{2}+\omega$, where $\tau$ is the duration between original sale and resale (measured in quarters), and $\omega$ is a normally distributed error term. In the third stage we re-estimate the mobile home price index model using a GLS estimation approach weighted by the square root of the estimated diffusion variance, $\hat{\varepsilon}(\tau)$, obtained from the second stage. Fore readability, the estimated mobile home price indices are not reported in the table.

\begin{tabular}{|c|c|c|c|}
\hline & $\begin{array}{c}\text { Impact of Rent Control } \\
\text { (1) }\end{array}$ & $\begin{array}{c}\text { Impact of Rent } \\
\text { (2) }\end{array}$ & $\begin{array}{l}\text { vith Other Effects } \\
\text { (3) }\end{array}$ \\
\hline Orange County & & $\begin{array}{l}-0.04 \\
(-8.79)\end{array}$ & $\begin{array}{l}-0.04 \\
(-8.38)\end{array}$ \\
\hline Riverside & & $\begin{array}{l}-0.28 \\
(-45.92)\end{array}$ & $\begin{array}{l}-0.27 \\
(-45.91)\end{array}$ \\
\hline San Bernardino & & $\begin{array}{l}-0.30 \\
(-55.88)\end{array}$ & $\begin{array}{l}-0.29 \\
(-55.03)\end{array}$ \\
\hline San Diego & & $\begin{array}{c}0.31 \\
(50.24)\end{array}$ & $\begin{array}{l}-0.03 \\
(-6.47)\end{array}$ \\
\hline Santa Clara & & $\begin{array}{l}-0.03 \\
(-6.17)\end{array}$ & $\begin{array}{c}0.33 \\
(53.87)\end{array}$ \\
\hline Ventura & & $\begin{array}{c}0.37 \\
(42.13)\end{array}$ & $\begin{array}{c}0.36 \\
(41.59)\end{array}$ \\
\hline Double & & $\begin{array}{c}0.19 \\
(30.34)\end{array}$ & $\begin{array}{c}0.19 \\
(30.39)\end{array}$ \\
\hline Triple & & $\begin{array}{c}0.26 \\
(21.25)\end{array}$ & $\begin{array}{c}0.27 \\
(21.46)\end{array}$ \\
\hline Size & & $\begin{array}{c}1.63 \mathrm{E}-05 \\
(2.47) \\
-1.39 \\
(-39.57)\end{array}$ & $\begin{array}{c}1.67 \mathrm{E}-05 \\
(2.54) \\
-1.34 \\
(-38.18)\end{array}$ \\
\hline Under rent control without vacancy decontrol & & $\begin{array}{c}0.01 \\
(1.44)\end{array}$ & $\begin{array}{c}0.01 \\
(1.10)\end{array}$ \\
\hline Under rent control with vacancy decontrol & & $\begin{array}{l}-0.02 \\
(-1.85)\end{array}$ & $\begin{array}{l}-0.02 \\
(-1.88)\end{array}$ \\
\hline Adoption of rent control without vacancy decontrol & $\begin{array}{c}0.15 \\
(28.77)\end{array}$ & $\begin{array}{c}0.12 \\
(23.22)\end{array}$ & \\
\hline $\begin{array}{l}\text { Adoption of rent control without vacancy decontrol } \\
\times \text { number of months years under rent control }\end{array}$ & & & $\begin{array}{c}0.015 \\
(30.06)\end{array}$ \\
\hline Adoption of rent control with vacancy decontrol & $\begin{array}{c}-0.11 \\
(-20.70)\end{array}$ & $\begin{array}{c}-0.09 \\
(-16.57)\end{array}$ & $\begin{array}{c}-0.08 \\
(-15.76)\end{array}$ \\
\hline R square & 0.412 & 0.496 & 0.498 \\
\hline Sample size & 137,221 & 137,221 & 137,221 \\
\hline
\end{tabular}


Figure 3. Logarithm of Price Growth Rate by Income and Age Sub-Groups

These figures present the box plot of the logarithm of price growth rates by various sub-groups. The boxes contain the middle 50 percent of the data. The upper edges of the boxes indicate the $75^{\text {th }}$ percentile of the data set, and the lower edges indicate the $25^{\text {th }}$ percentile. The lines in the boxes indicate the median value of the data. The ends of the vertical lines indicate the minimum and maximum data values. The logarithm of price growth rate is defined as: $\ln \left(\frac{P_{t+\tau}}{P_{t}}\right)$, where $\ln (\cdot)$ is natural logarithm function, $P_{t+\tau}$ is the resale price after $\tau$ periods since the original sale at $t, P_{t}$ is the original sales price at $t$.

Figure 3a. Logarithm of Price Growth Rate by Income Group

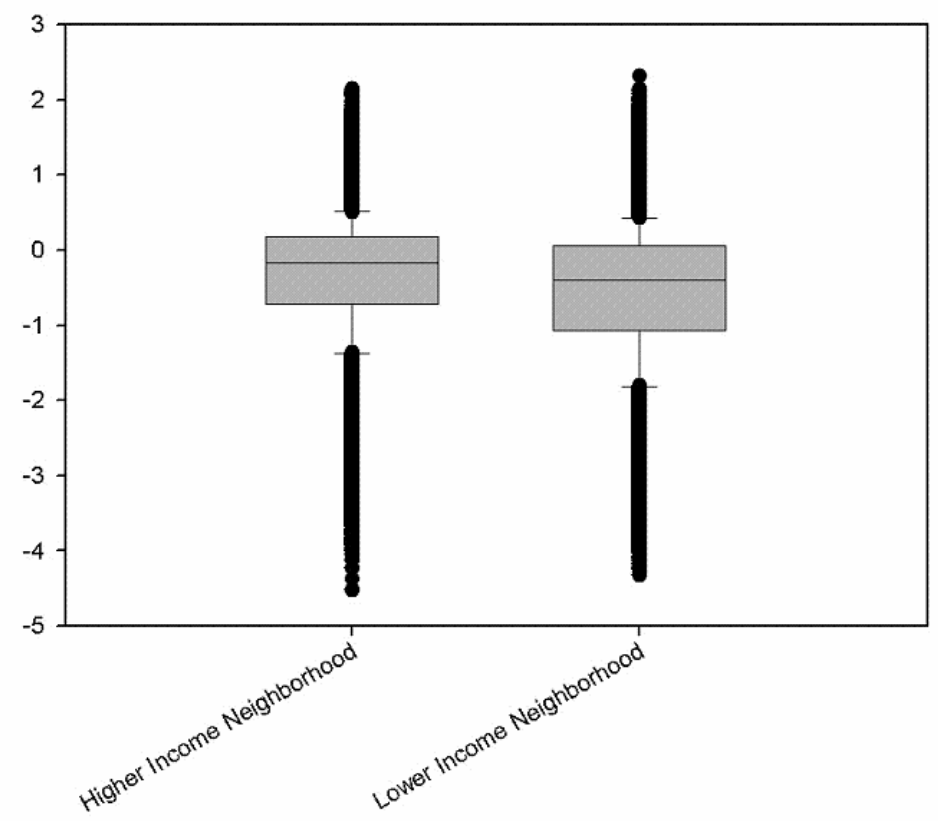

Figure 3b. Logarithm of Price Growth Rate by Age Group

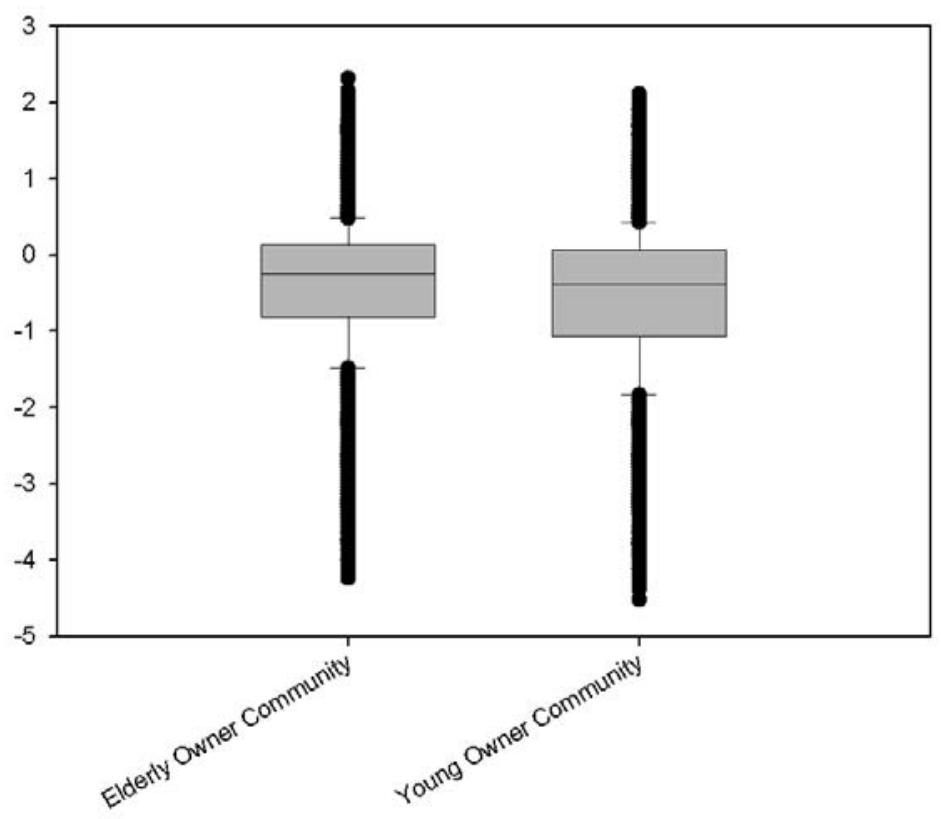




\section{Table 7. GLS Estimates for Logarithm of Price Growth Rate, by Subgroups}

The table reports rent control impacts on mobile home prices. We estimate the rent control impact by decomposing the capitalization of rent control premium from a repeated-sales mobile home price index model specified in equations (9) and (10) using a three-stage GLS estimation approach. In the first stage, we use OLS to estimate the following mobile home price index model which decomposes the rent control premium capitalization from the mobile home price appreciation: $\ln \left(\frac{P_{t+\tau}}{P_{t}}\right)=D^{\prime} \gamma+Z^{\prime} \theta+\left(R C_{t+\tau}-R C_{t}\right)^{\prime} \delta+\mu(\tau)$, where $\ln (\cdot)$ is natural logarithm function, $P_{t+\tau}$ is the resale price after $\tau$

periods since the original sale at $t, P_{t}$ is the original sales price at $t, D$ is a repeated-sales transaction vector composed of $-1,0$ and $1 ; R C$ is a vector of indicator variables to capture the rent control premium capitalization; $Z$ is a vector of hedonic characteristics capturing the location effect (measured by county), and coach structure characteristics, such as single, double, or triple-width, size, and neighborhood quality, etc., and $\mu$ is the normally distributed error term with a diffusion variance varying by the time span between two transactions. In the second stage, we estimate a diffusion process of the mobile home price index by regressing the square term of residuals, $\varepsilon^{2}$, collected from the first stage OLS regression on a quadratic function of time span between the two sales, such that, $\varepsilon(\tau)^{2}=\beta_{1} \tau+\beta_{2} \tau^{2}+\omega$, where $\tau$ is the duration between original sale and resale (measured in quarters), and $\omega$ is a normally distributed error term. In the third stage we re-estimate the mobile home price index model using a GLS estimation approach weighted by the square root of the estimated diffusion variance, $\hat{\varepsilon}(\tau)$, obtained from the second stage. Fore readability, the estimated mobile home price indices are not reported in the table. 
Table 7a. GLS Estimates for Logarithm of Price Growth Rate, by Census Tract Household Income

\begin{tabular}{lcc}
\hline \hline & Higher Median Household & Lower Median Household \\
& Income & -0.07 \\
Orange County & 0.04 & $(-9.53)$ \\
Riverside & $(4.49)$ & -0.34 \\
& -0.17 & $(-39.15)$ \\
San Bernardino & $-18.21)$ & -0.35 \\
& -0.23 & $(-44.49)$ \\
San Diego & $-29.81)$ & 0.36 \\
& 0.17 & $(42.96)$ \\
Santa Clara & $(13.57)$ & -0.004 \\
& -0.061 & $(-0.58)$ \\
Ventura & $(-9.10)$ & 0.37 \\
& 0.37 & $(33.58)$ \\
Double & $(22.29)$ & 0.20 \\
& 0.17 & $(24.68)$ \\
Triple & $(16.65)$ & 0.27 \\
& 0.25 & $(15.55)$ \\
Size & $(13.41)$ & $4.10 \mathrm{E}-05$ \\
Proportion of households with public assistance income & $-1.22 \mathrm{E}-05$ & $(4.46)$ \\
& $(-1.23)$ & -1.00 \\
Under rent control without vacancy decontrol & -2.10 & $(-22.94)$ \\
Under rent control with vacancy decontrol & $(-26.47)$ & -0.014 \\
& 0.070 & $(-1.04)$ \\
Adoption of rent control without vacancy decontrol & $(4.90)$ & 0.01 \\
& -0.02 & $(0.44)$ \\
Adoption of rent control with vacancy decontrol & $(-1.95)$ & 0.12 \\
R square & 0.16 & $(18.21)$ \\
Sample size & $(18.40)$ & -0.05 \\
& -0.11 & $(-7.40)$ \\
& $(-14.12)$ & 0.54 \\
& 0.44 & 84,300 \\
\hline
\end{tabular}


Table 7b. GLS Estimates for Logarithm of Price Growth Rate, by Census Tract Proportion of Elderly Population

\begin{tabular}{|c|c|c|}
\hline & $\begin{array}{c}\text { Higher Proportion of Elderly } \\
\text { Population }\end{array}$ & $\begin{array}{c}\text { Lower Proportion of Elderly } \\
\text { Population }\end{array}$ \\
\hline Orange County & $\begin{array}{l}-0.05 \\
(-6.50)\end{array}$ & $\begin{array}{l}-0.03 \\
(-4.75)\end{array}$ \\
\hline Riverside & $\begin{array}{c}-0.36 \\
(-40.69)\end{array}$ & $\begin{array}{c}-0.21 \\
(-25.65)\end{array}$ \\
\hline San Bernardino & $\begin{array}{c}-0.41 \\
(-54.09)\end{array}$ & $\begin{array}{c}-0.19 \\
(-25.75)\end{array}$ \\
\hline San Diego & $\begin{array}{c}0.32 \\
(36.98)\end{array}$ & $\begin{array}{c}0.31 \\
(33.88)\end{array}$ \\
\hline Santa Clara & $\begin{array}{c}-0.08 \\
(-11.78)\end{array}$ & $\begin{array}{c}0.03 \\
(3.94)\end{array}$ \\
\hline Ventura & $\begin{array}{c}0.33 \\
(26.63)\end{array}$ & $\begin{array}{c}0.41 \\
(33.51)\end{array}$ \\
\hline Double & $\begin{array}{c}0.17 \\
(18.40)\end{array}$ & $\begin{array}{c}0.21 \\
(24.56)\end{array}$ \\
\hline Triple & $\begin{array}{c}0.23 \\
(13.26)\end{array}$ & $\begin{array}{c}0.26 \\
(14.78)\end{array}$ \\
\hline Size & $\begin{array}{l}4.99 \mathrm{E}-05 \\
(5.21)\end{array}$ & $\begin{array}{c}-2.63 \mathrm{E}-05 \\
(-2.96)\end{array}$ \\
\hline Proportion of households with public assistance income & $\begin{array}{c}-1.13 \\
(-19.42)\end{array}$ & $\begin{array}{l}-1.21 \\
(-27.02)\end{array}$ \\
\hline Under rent control without vacancy decontrol & $\begin{array}{c}0.06 \\
(4.29)\end{array}$ & $\begin{array}{l}-0.03 \\
(-2.51)\end{array}$ \\
\hline Under rent control with vacancy decontrol & $\begin{array}{c}0.02 \\
(1.73)\end{array}$ & $\begin{array}{c}-0.03 \\
(-2.54)\end{array}$ \\
\hline Adoption of rent control without vacancy decontrol & $\begin{array}{c}0.08 \\
(11.50)\end{array}$ & $\begin{array}{c}0.21 \\
(24.80)\end{array}$ \\
\hline Adoption of rent control with vacancy decontrol & $\begin{array}{l}-0.02 \\
(-2.90)\end{array}$ & $\begin{array}{c}-0.14 \\
(-17.16)\end{array}$ \\
\hline R square & 0.48 & 0.52 \\
\hline Sample size & 69,547 & 67,674 \\
\hline
\end{tabular}


Table 7c. GLS Estimates for Logarithm of Price Growth Rate, by Census Tract Median Household Income and Proportion of Elderly Population

\begin{tabular}{|c|c|c|c|c|}
\hline & $\begin{array}{l}\text { High Income \& High } \\
\text { Proportion of Elderly }\end{array}$ & $\begin{array}{l}\text { High Income \& Low } \\
\text { Proportion of Elderly }\end{array}$ & $\begin{array}{l}\text { Low Income \& High } \\
\text { Proportion of Elderly }\end{array}$ & $\begin{array}{l}\text { Low Income \& Low } \\
\text { Proportion of Elderly }\end{array}$ \\
\hline Orange County & $\begin{array}{c}0.08 \\
(6.96)\end{array}$ & $\begin{array}{c}0.01 \\
(1.01)\end{array}$ & $\begin{array}{l}-0.02 \\
(-1.98)\end{array}$ & $\begin{array}{c}-0.10 \\
(-10.25)\end{array}$ \\
\hline Riverside & $\begin{array}{l}-0.21 \\
(-9.93)\end{array}$ & $\begin{array}{c}-0.11 \\
(-10.58)\end{array}$ & $\begin{array}{c}-0.32 \\
(-27.73)\end{array}$ & $\begin{array}{c}-0.35 \\
(-27.11)\end{array}$ \\
\hline San Bernardino & $\begin{array}{c}-0.47 \\
(-33.53)\end{array}$ & $\begin{array}{c}-0.11 \\
(-11.69)\end{array}$ & $\begin{array}{c}-0.35 \\
(-32.54)\end{array}$ & $\begin{array}{c}-0.34 \\
(-27.66)\end{array}$ \\
\hline San Diego & $\begin{array}{c}0.33 \\
(15.24)\end{array}$ & $\begin{array}{c}0.15 \\
(9.68)\end{array}$ & $\begin{array}{c}0.40 \\
(34.83)\end{array}$ & $\begin{array}{c}0.31 \\
(24.44)\end{array}$ \\
\hline Santa Clara & $\begin{array}{l}-0.10 \\
(-9.92)\end{array}$ & $\begin{array}{l}-0.02 \\
(-1.91)\end{array}$ & $\begin{array}{c}0.01 \\
(0.78)\end{array}$ & $\begin{array}{c}0.01 \\
(1.14)\end{array}$ \\
\hline Ventura & $\begin{array}{c}0.34 \\
(10.94)\end{array}$ & $\begin{array}{c}0.40 \\
(20.03)\end{array}$ & $\begin{array}{c}0.42 \\
(28.25)\end{array}$ & $\begin{array}{c}0.33 \\
(18.97)\end{array}$ \\
\hline Double & $\begin{array}{l}0.16 \\
(9.70)\end{array}$ & $\begin{array}{c}0.17 \\
(13.29)\end{array}$ & $\begin{array}{c}0.19 \\
(16.54)\end{array}$ & $\begin{array}{c}0.22 \\
(18.68)\end{array}$ \\
\hline Triple & $\begin{array}{c}0.26 \\
(9.18)\end{array}$ & $\begin{array}{c}0.18 \\
(7.68)\end{array}$ & $\begin{array}{c}0.26 \\
(11.60)\end{array}$ & $\begin{array}{c}0.25 \\
(9.51)\end{array}$ \\
\hline Size & $\begin{array}{c}-1.58 \mathrm{E}-05 \\
(-1.01)\end{array}$ & $\begin{array}{c}-1.24 \mathrm{E}-05 \\
(-0.99)\end{array}$ & $\begin{array}{l}4.04 \mathrm{E}-05 \\
(3.19)\end{array}$ & $\begin{array}{l}2.85 \mathrm{E}-05 \\
(2.12)\end{array}$ \\
\hline $\begin{array}{l}\text { Proportion of households } \\
\text { with public assistance } \\
\text { income }\end{array}$ & $\begin{array}{l}-0.99 \\
(-6.62)\end{array}$ & $\begin{array}{l}-2.09 \\
(-22.27)\end{array}$ & $\begin{array}{l}-0.88 \\
(-12.72)\end{array}$ & $\begin{array}{l}-0.97 \\
(-16.14)\end{array}$ \\
\hline $\begin{array}{l}\text { Under rent control without } \\
\text { vacancy decontrol }\end{array}$ & $\begin{array}{l}0.15 \\
(6.64)\end{array}$ & $\begin{array}{l}-0.01 \\
(-0.34)\end{array}$ & $\begin{array}{l}-0.04 \\
(-1.98)\end{array}$ & $\begin{array}{c}0.02 \\
(1.11)\end{array}$ \\
\hline $\begin{array}{l}\text { Under rent control with } \\
\text { vacancy decontrol }\end{array}$ & $\begin{array}{l}-0.011 \\
(-0.43)\end{array}$ & $\begin{array}{l}-0.003 \\
(-0.20)\end{array}$ & $\begin{array}{l}0.022 \\
(1.30)\end{array}$ & $\begin{array}{l}0.009 \\
(0.57)\end{array}$ \\
\hline $\begin{array}{l}\text { Adoption of rent control } \\
\text { without vacancy decontrol }\end{array}$ & $\begin{array}{c}0.11 \\
(8.49)\end{array}$ & $\begin{array}{c}0.26 \\
(19.93)\end{array}$ & $\begin{array}{c}0.06 \\
(7.82)\end{array}$ & $\begin{array}{c}0.22 \\
(19.23)\end{array}$ \\
\hline $\begin{array}{l}\text { Adoption of rent control with } \\
\text { vacancy decontrol }\end{array}$ & $\begin{array}{l}0.031 \\
(2.53)\end{array}$ & $\begin{array}{c}-0.148 \\
(-14.08)\end{array}$ & $\begin{array}{l}-0.03 \\
(-2.89)\end{array}$ & $\begin{array}{l}-0.07 \\
(-6.06)\end{array}$ \\
\hline $\mathrm{R}$ square & 0.41 & 0.49 & 0.53 & 0.55 \\
\hline Sample size & 24,826 & 28,095 & 44,721 & 39,579 \\
\hline
\end{tabular}


Table 8. Repeat Sale Price Index (1983=100)

\begin{tabular}{|c|c|c|c|}
\hline Quarter & Index & Quarter & Index \\
\hline $1983-1$ & 100.00 & $1993-2$ & 52.75 \\
\hline $1983-2$ & 110.70 & 1993-3 & 50.64 \\
\hline $1983-3$ & 115.93 & $1993-4$ & 44.60 \\
\hline $1983-4$ & 116.74 & 1994-1 & 47.65 \\
\hline $1984-1$ & 105.00 & $1994-2$ & 42.06 \\
\hline $1984-2$ & 116.80 & $1994-3$ & 40.84 \\
\hline $1984-3$ & 118.28 & $1994-4$ & 39.79 \\
\hline $1984-4$ & 119.37 & $1995-1$ & 43.23 \\
\hline $1985-1$ & 100.65 & $1995-2$ & 37.77 \\
\hline $1985-2$ & 115.81 & $1995-3$ & 37.31 \\
\hline $1985-3$ & 118.67 & $1995-4$ & 37.47 \\
\hline $1985-4$ & 116.06 & $1996-1$ & 41.33 \\
\hline $1986-1$ & 97.77 & $1996-2$ & 35.19 \\
\hline $1986-2$ & 115.64 & $1996-3$ & 36.88 \\
\hline $1986-3$ & 117.35 & $1996-4$ & 35.23 \\
\hline $1986-4$ & 116.39 & $1997-1$ & 44.32 \\
\hline $1987-1$ & 100.26 & $1997-2$ & 34.84 \\
\hline $1987-2$ & 113.32 & $1997-3$ & 36.62 \\
\hline $1987-3$ & 115.11 & $1997-4$ & 39.27 \\
\hline $1987-4$ & 111.95 & $1998-1$ & 48.01 \\
\hline $1988-1$ & 101.38 & $1998-2$ & 40.16 \\
\hline $1988-2$ & 111.78 & $1998-3$ & 41.21 \\
\hline $1988-3$ & 114.57 & $1998-4$ & 41.63 \\
\hline $1988-4$ & 113.21 & $1999-1$ & 48.82 \\
\hline $1989-1$ & 96.10 & $1999-2$ & 43.78 \\
\hline $1989-2$ & 110.82 & $1999-3$ & 42.99 \\
\hline $1989-3$ & 114.37 & $1999-4$ & 44.06 \\
\hline $1989-4$ & 111.61 & $2000-1$ & 50.04 \\
\hline $1990-1$ & 93.16 & $2000-2$ & 46.18 \\
\hline $1990-2$ & 108.98 & $2000-3$ & 49.03 \\
\hline $1990-3$ & 107.49 & $2000-4$ & 51.35 \\
\hline $1990-4$ & 99.47 & $2001-1$ & 52.00 \\
\hline 1991-1 & 80.86 & $2001-2$ & 50.78 \\
\hline $1991-2$ & 89.73 & 2001-3 & 52.30 \\
\hline $1991-3$ & 88.68 & 2001-4 & 51.92 \\
\hline $1991-4$ & 80.06 & $2002-1$ & 51.85 \\
\hline $1992-1$ & 71.82 & $2002-2$ & 52.18 \\
\hline $1992-2$ & 72.18 & $2002-3$ & 55.11 \\
\hline $1992-3$ & 67.98 & $2002-4$ & 55.70 \\
\hline $1992-4$ & 61.27 & 2003-1 & 52.07 \\
\hline 1993-1 & 54.38 & $2003-2$ & 56.63 \\
\hline
\end{tabular}


Figure 4a. Full Sample Index

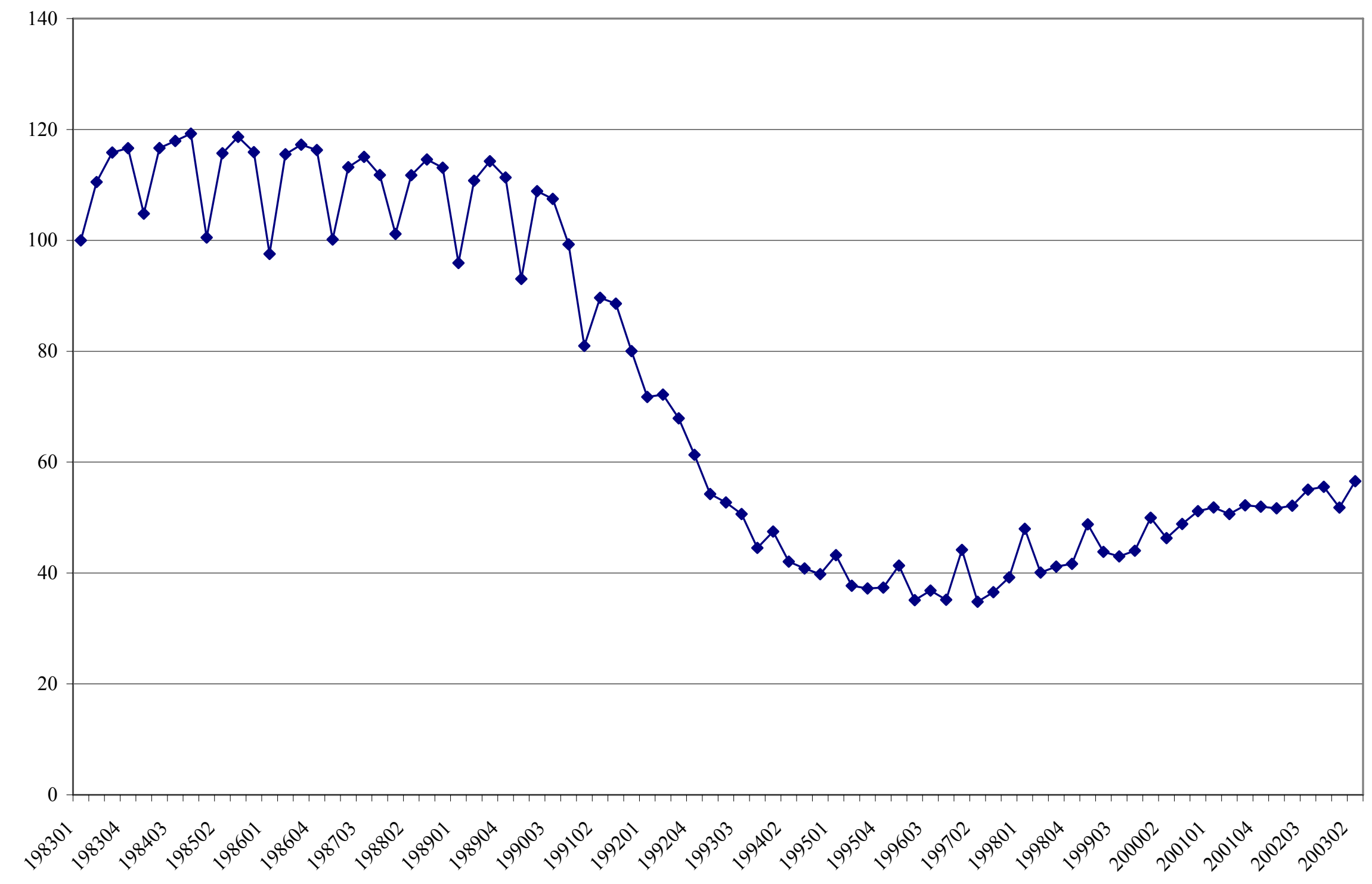

40 


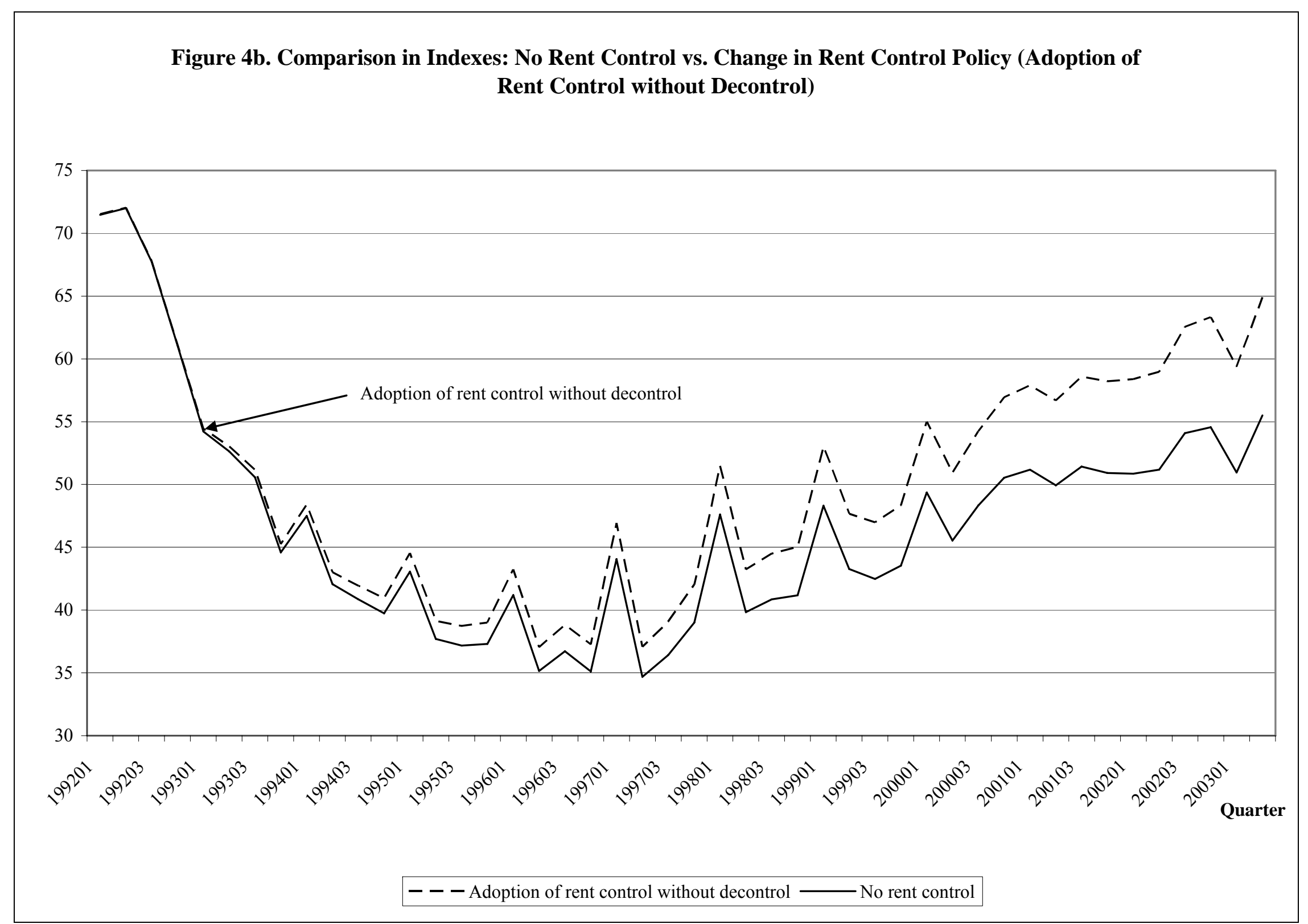


Table 9. Resale Price Comparison for an Average 19 years old Structure in Los Angeles

The following Tables present the estimated resale prices for the average 19 years old mobile home units in each subgroup in Los Angeles County, under different rent control regimes. The average unit is defined as the one with average structure (double, triple), in census tract with average proportion of households with public assistance income, etc. By using the average units' characteristics and the parameters estimated in Table 7, we can simulate the resale prices as presented here.

Table 9a. Resale Price Comparison for an Average 19 years old Structure in Los Angeles

\begin{tabular}{l|ccccc}
\hline \hline \multirow{2}{*}{$\begin{array}{l}\text { Resale price } \\
\text { comparison for an } \\
\text { average 19 years old } \\
\text { structure }\end{array}$} & $\begin{array}{l}\text { No rent } \\
\text { control }\end{array}$ & $\begin{array}{c}\text { Under rent } \\
\text { control } \\
\text { without } \\
\text { vacancy } \\
\text { decontrol }\end{array}$ & $\begin{array}{c}\text { Under rent } \\
\text { control with } \\
\text { vacancy } \\
\text { decontrol }\end{array}$ & $\begin{array}{c}\text { Adoption of } \\
\text { rent control } \\
\text { without } \\
\text { vacancy } \\
\text { decontrol }\end{array}$ & $\begin{array}{c}\text { Adoption of } \\
\text { rent control } \\
\text { with vacancy } \\
\text { decontrol }\end{array}$ \\
\hline $\begin{array}{l}\text { Resale price } \\
\text { Price increase }\end{array}$ & $\$ 43,263$ & $\$ 43,263$ & $\$ 42,588$ & $\$ 48,824$ & $\$ 39,656$ \\
$\begin{array}{l}\text { Growth rate } \\
\text { (percentage) }\end{array}$ & $\$ 2,519$ & $\$ 2,519$ & $\$ 1,845$ & $\$ 8,081$ & $-\$ 1,088$ \\
$\begin{array}{l}\text { Growth out from rent } \\
\text { control (percentage) }\end{array}$ & - & 6.18 & 4.53 & 19.83 & -2.67 \\
\hline \hline
\end{tabular}


Table 9b. Resale Price Comparison for an Average 19 years old Structure in Los Angeles, Different Income Communities

\begin{tabular}{|c|c|c|c|c|c|c|c|c|c|c|}
\hline \multirow[b]{2}{*}{$\begin{array}{l}\text { Resale price } \\
\text { comparison for an } \\
\text { average } 19 \text { years old } \\
\text { structure }\end{array}$} & \multicolumn{5}{|c|}{ "High Median Household Income } & \multicolumn{5}{|c|}{ "Low Median Household Income } \\
\hline & $\begin{array}{l}\text { No rent } \\
\text { control }\end{array}$ & $\begin{array}{c}\text { Under rent } \\
\text { control } \\
\text { without } \\
\text { vacancy } \\
\text { decontrol } \\
\end{array}$ & $\begin{array}{l}\text { Under rent } \\
\text { control with } \\
\text { vacancy } \\
\text { decontrol }\end{array}$ & $\begin{array}{c}\text { Adoption of } \\
\text { rent control } \\
\text { without } \\
\text { vacancy } \\
\text { decontrol } \\
\end{array}$ & $\begin{array}{c}\text { Adoption of } \\
\text { rent control } \\
\text { with vacancy } \\
\text { decontrol }\end{array}$ & $\begin{array}{l}\text { No rent } \\
\text { control }\end{array}$ & $\begin{array}{c}\text { Under rent } \\
\text { control } \\
\text { without } \\
\text { vacancy } \\
\text { decontrol } \\
\end{array}$ & $\begin{array}{l}\text { Under rent } \\
\text { control with } \\
\text { vacancy } \\
\text { decontrol }\end{array}$ & $\begin{array}{l}\text { Adoption of } \\
\text { rent control } \\
\text { without } \\
\text { vacancy } \\
\text { decontrol } \\
\end{array}$ & $\begin{array}{c}\text { Adoption of } \\
\text { rent control } \\
\text { with vacancy } \\
\text { decontrol }\end{array}$ \\
\hline Resale price & $\$ 43,500$ & $\$ 46,760$ & $\$ 42,427$ & $\$ 51,538$ & $\$ 38,731$ & $\$ 38,237$ & $\$ 38,237$ & $\$ 38,418$ & $\$ 42,664$ & $\$ 36,406$ \\
\hline Price increase & $\$ 366$ & $\$ 3,625$ & $-\$ 707$ & $\$ 8,403$ & $-\$ 4,403$ & $\$ 2,744$ & $\$ 2,744$ & $\$ 2,926$ & $\$ 7,172$ & $\$ 914$ \\
\hline $\begin{array}{l}\text { Growth rate } \\
\text { (percentage) }\end{array}$ & 0.85 & 8.40 & -1.64 & 19.48 & -10.21 & 7.73 & 7.73 & 8.24 & 20.21 & 2.57 \\
\hline $\begin{array}{l}\text { Growth out from rent } \\
\text { control (percentage) }\end{array}$ & - & 7.56 & -2.49 & 18.63 & -11.05 & - & 0 & 0.51 & 12.47 & -5.16 \\
\hline
\end{tabular}

Table 9c. Resale Price Comparison for an Average 19 years old Structure in Los Angeles, Different Age Communities

\begin{tabular}{|c|c|c|c|c|c|c|c|c|c|c|}
\hline \multirow[b]{2}{*}{$\begin{array}{l}\text { Resale price } \\
\text { comparison for an } \\
\text { average } 19 \text { years old } \\
\text { structure }\end{array}$} & \multicolumn{5}{|c|}{ High Proportion of Elderly Population } & \multicolumn{5}{|c|}{ Low Proportion of Elderly Population } \\
\hline & $\begin{array}{l}\text { No rent } \\
\text { control }\end{array}$ & $\begin{array}{l}\text { Under rent } \\
\text { control } \\
\text { without } \\
\text { vacancy } \\
\text { decontrol } \\
\end{array}$ & $\begin{array}{l}\text { Under rent } \\
\text { control with } \\
\text { vacancy } \\
\text { decontrol }\end{array}$ & $\begin{array}{l}\text { Adoption of } \\
\text { rent control } \\
\text { without } \\
\text { vacancy } \\
\text { decontrol } \\
\end{array}$ & $\begin{array}{l}\text { Adoption of } \\
\text { rent control } \\
\text { with vacancy } \\
\text { decontrol }\end{array}$ & $\begin{array}{l}\text { No rent } \\
\text { control }\end{array}$ & $\begin{array}{l}\text { Under rent } \\
\text { control } \\
\text { without } \\
\text { vacancy } \\
\text { decontrol } \\
\end{array}$ & $\begin{array}{l}\text { Under rent } \\
\text { control with } \\
\text { vacancy } \\
\text { decontrol }\end{array}$ & $\begin{array}{l}\text { Adoption of } \\
\text { rent control } \\
\text { without } \\
\text { vacancy } \\
\text { decontrol } \\
\end{array}$ & $\begin{array}{l}\text { Adoption of } \\
\text { rent control } \\
\text { with vacancy } \\
\text { decontrol }\end{array}$ \\
\hline Resale price & $\$ 47,383$ & $\$ 50,199$ & $\$ 48,503$ & $\$ 51,030$ & $\$ 46,435$ & $\$ 39,892$ & $\$ 38,574$ & $\$ 38,796$ & $\$ 49,560$ & $\$ 34,617$ \\
\hline Price increase & $\$ 4,903$ & $\$ 7,720$ & $\$ 6,024$ & $\$ 8,550$ & $\$ 3,956$ & $\$ 938$ & $-\$ 381$ & $-\$ 159$ & $\$ 10,605$ & $-\$ 4,338$ \\
\hline (percentage) & 11.54 & 18.17 & 14.18 & 20.13 & 9.31 & 2.41 & -0.98 & -0.41 & 27.22 & -11.14 \\
\hline $\begin{array}{l}\text { Growth out from rent } \\
\text { control (percentage) }\end{array}$ & - & 6.63 & 2.64 & 8.59 & -2.23 & - & -3.38 & -2.82 & 24.82 & -13.54 \\
\hline
\end{tabular}


Table 9d. Resale Price Comparison for an Average 19 years old Structure in Los Angeles, Different Income and Age Communities

\begin{tabular}{|c|c|c|c|c|c|c|c|c|c|c|}
\hline \multirow[b]{2}{*}{$\begin{array}{l}\text { Resale price } \\
\text { comparison for an } \\
\text { average } 19 \text { years old } \\
\text { structure }\end{array}$} & \multicolumn{5}{|c|}{ High Income \& High Proportion of Elderly } & \multicolumn{5}{|c|}{ High Income \& Low Proportion of Elderly } \\
\hline & $\begin{array}{l}\text { No rent } \\
\text { control }\end{array}$ & $\begin{array}{l}\text { Under rent } \\
\text { control } \\
\text { without } \\
\text { vacancy } \\
\text { decontrol }\end{array}$ & $\begin{array}{l}\text { Under rent } \\
\text { control with } \\
\text { vacancy } \\
\text { decontrol }\end{array}$ & $\begin{array}{l}\text { Adoption of } \\
\text { rent control } \\
\text { without } \\
\text { vacancy } \\
\text { decontrol } \\
\end{array}$ & $\begin{array}{l}\text { Adoption of } \\
\text { rent control } \\
\text { with vacancy } \\
\text { decontrol }\end{array}$ & $\begin{array}{l}\text { No rent } \\
\text { control }\end{array}$ & $\begin{array}{l}\text { Under rent } \\
\text { control } \\
\text { without } \\
\text { vacancy } \\
\text { decontrol }\end{array}$ & $\begin{array}{l}\text { Under rent } \\
\text { control with } \\
\text { vacancy } \\
\text { decontrol }\end{array}$ & $\begin{array}{l}\text { Adoption of } \\
\text { rent control } \\
\text { without } \\
\text { vacancy } \\
\text { decontrol } \\
\end{array}$ & $\begin{array}{l}\text { Adoption of } \\
\text { rent control } \\
\text { with vacancy } \\
\text { decontrol }\end{array}$ \\
\hline Resale price & $\$ 47,132$ & $\$ 54,326$ & $\$ 47,132$ & $\$ 52,407$ & $\$ 48,534$ & $\$ 41,229$ & $\$ 41,229$ & $\$ 41,229$ & $\$ 55,365$ & $\$ 34,640$ \\
\hline Price increase & $\$ 3,069$ & $\$ 10,263$ & $\$ 3,069$ & $\$ 8,344$ & $\$ 4,471$ & $-\$ 799$ & $-\$ 799$ & $-\$ 799$ & $\$ 13,337$ & $-\$ 7,388$ \\
\hline $\begin{array}{l}\text { Growth rate } \\
\text { (percentage) }\end{array}$ & 6.97 & 23.29 & 6.97 & 18.94 & 10.15 & -1.90 & -1.90 & -1.90 & 31.73 & -17.58 \\
\hline $\begin{array}{l}\text { Growth out from rent } \\
\text { control (percentage) }\end{array}$ & - & 16.33 & 0 & 11.97 & 3.18 & - & 0 & 0 & 33.63 & -15.68 \\
\hline
\end{tabular}

\begin{tabular}{|c|c|c|c|c|c|c|c|c|c|c|}
\hline \multirow[b]{2}{*}{$\begin{array}{l}\text { Resale price } \\
\text { comparison for an } \\
\text { average } 19 \text { years old } \\
\text { structure }\end{array}$} & \multicolumn{5}{|c|}{ Low Income \& High Proportion of Elderly } & \multicolumn{5}{|c|}{ Low Income \& Low Proportion of Elderly } \\
\hline & $\begin{array}{l}\text { No rent } \\
\text { control }\end{array}$ & $\begin{array}{l}\text { Under rent } \\
\text { control } \\
\text { without } \\
\text { vacancy } \\
\text { decontrol } \\
\end{array}$ & $\begin{array}{l}\text { Under rent } \\
\text { control with } \\
\text { vacancy } \\
\text { decontrol }\end{array}$ & $\begin{array}{l}\text { Adoption of } \\
\text { rent control } \\
\text { without } \\
\text { vacancy } \\
\text { decontrol } \\
\end{array}$ & $\begin{array}{l}\text { Adoption of } \\
\text { rent control } \\
\text { with vacancy } \\
\text { decontrol }\end{array}$ & $\begin{array}{l}\text { No rent } \\
\text { control }\end{array}$ & $\begin{array}{c}\text { Under rent } \\
\text { control } \\
\text { without } \\
\text { vacancy } \\
\text { decontrol } \\
\end{array}$ & $\begin{array}{l}\text { Under rent } \\
\text { control with } \\
\text { vacancy } \\
\text { decontrol }\end{array}$ & $\begin{array}{l}\text { Adoption of } \\
\text { rent control } \\
\text { without } \\
\text { vacancy } \\
\text { decontrol } \\
\end{array}$ & $\begin{array}{l}\text { Adoption of } \\
\text { rent control } \\
\text { with vacancy } \\
\text { decontrol }\end{array}$ \\
\hline Resale price & $\$ 41,807$ & $\$ 40,373$ & $\$ 41,807$ & $\$ 44,425$ & $\$ 40,751$ & $\$ 35,746$ & $\$ 35,746$ & $\$ 35,746$ & $\$ 43,491$ & $\$ 33,459$ \\
\hline Price increase & $\$ 3,743$ & $\$ 2,309$ & $\$ 3,743$ & $\$ 6,362$ & $\$ 2,687$ & $\$ 2,180$ & $\$ 2,180$ & $\$ 2,180$ & $\$ 9,924$ & $-\$ 107$ \\
\hline $\begin{array}{l}\text { Growth rate } \\
\text { (percentage) }\end{array}$ & 9.83 & 6.07 & 9.83 & 16.71 & 7.06 & 6.49 & 6.49 & 6.49 & 29.57 & -0.32 \\
\hline $\begin{array}{l}\text { Growth out from rent } \\
\text { control (percentage) }\end{array}$ & - & -3.77 & 0 & 6.88 & -2.77 & - & 0 & 0 & 23.07 & -6.81 \\
\hline
\end{tabular}


Figure 5. Simulation Results: Resale Price Comparison for Los Angeles County

The following figures present the estimated resale prices for the average 19 years old mobile home units in each subgroup in Los Angeles County, under different rent control regimes. The average unit is defined as the one with average structure (double, triple), in census tract with average proportion of households with public assistance income, etc.

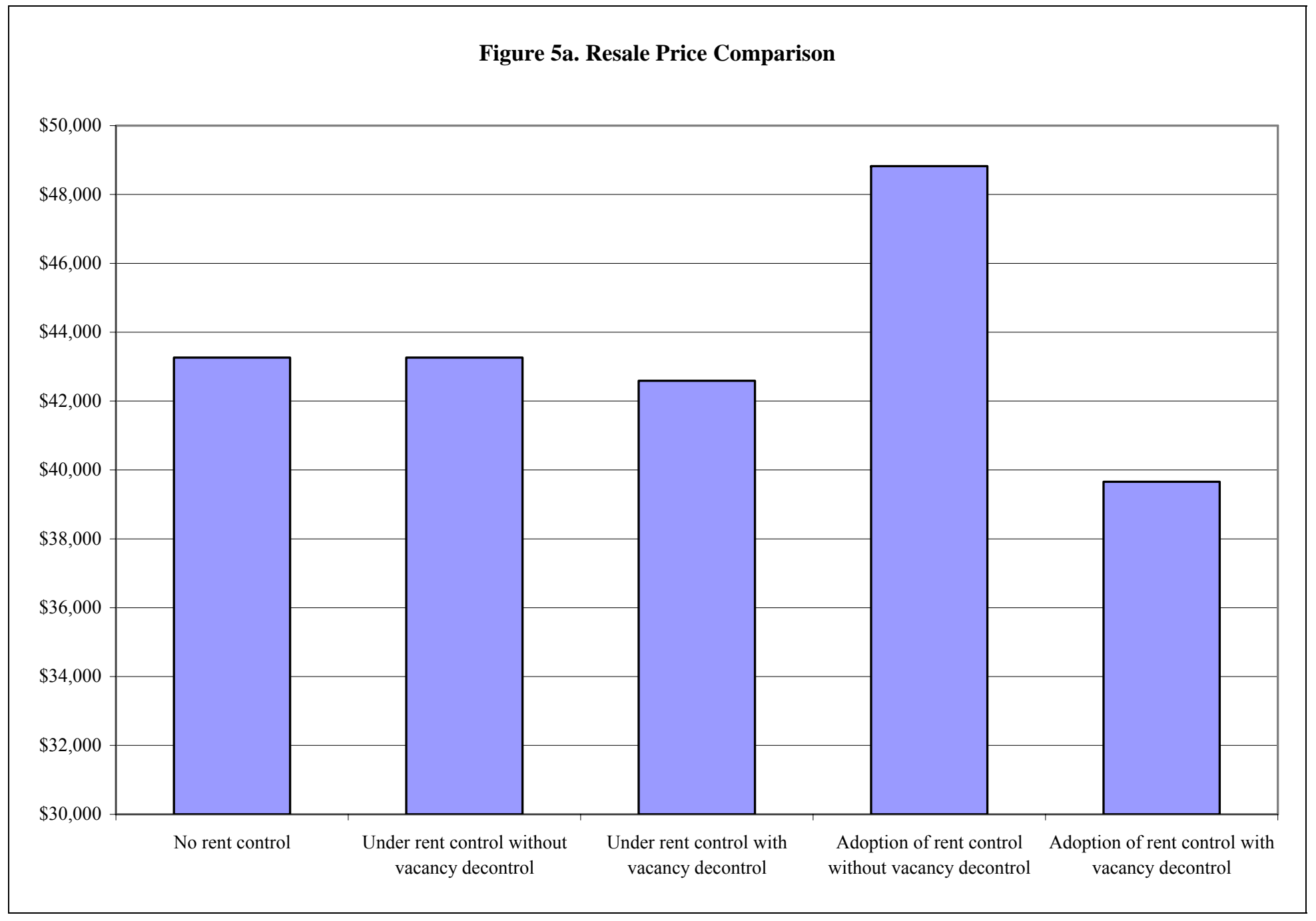




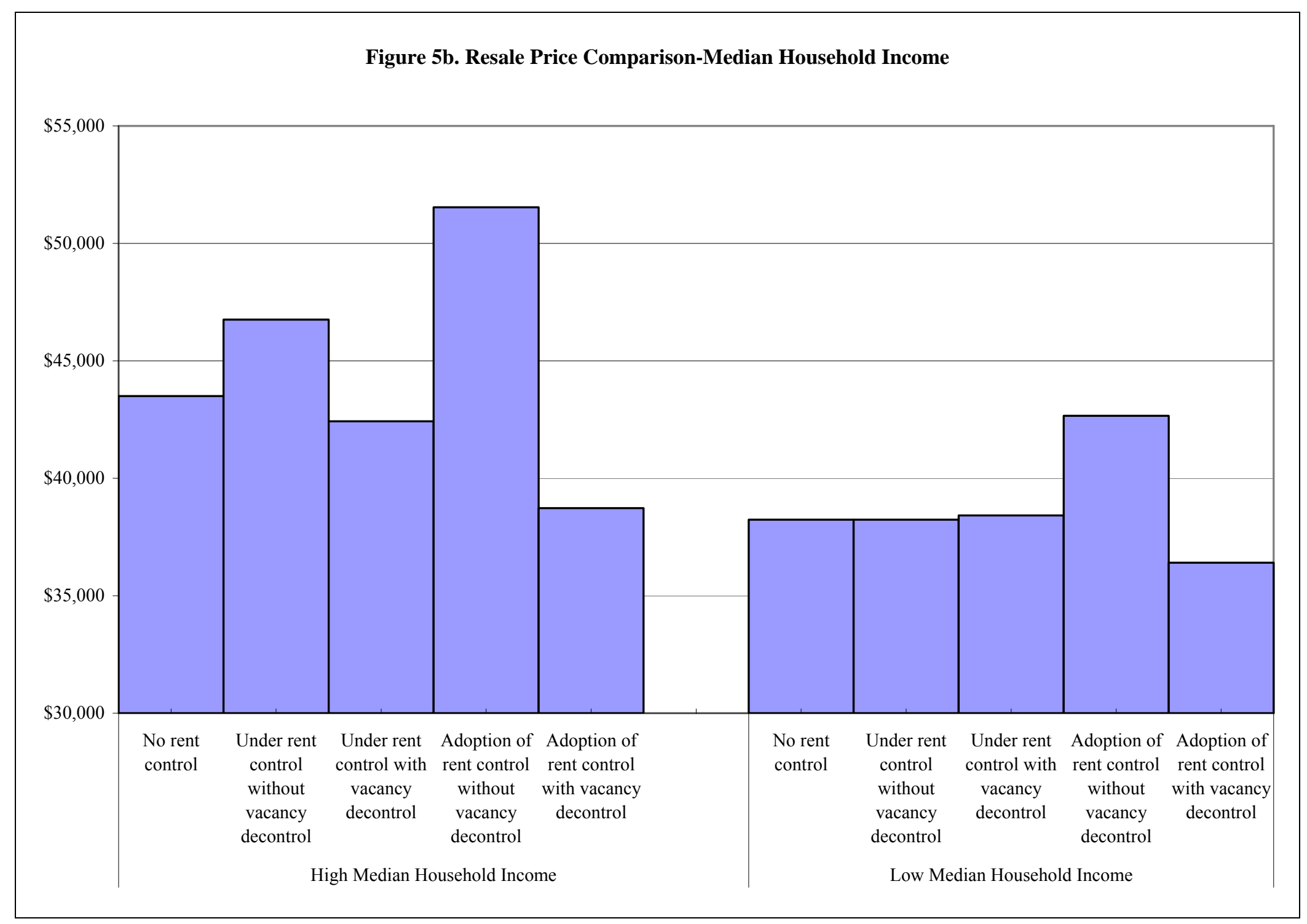




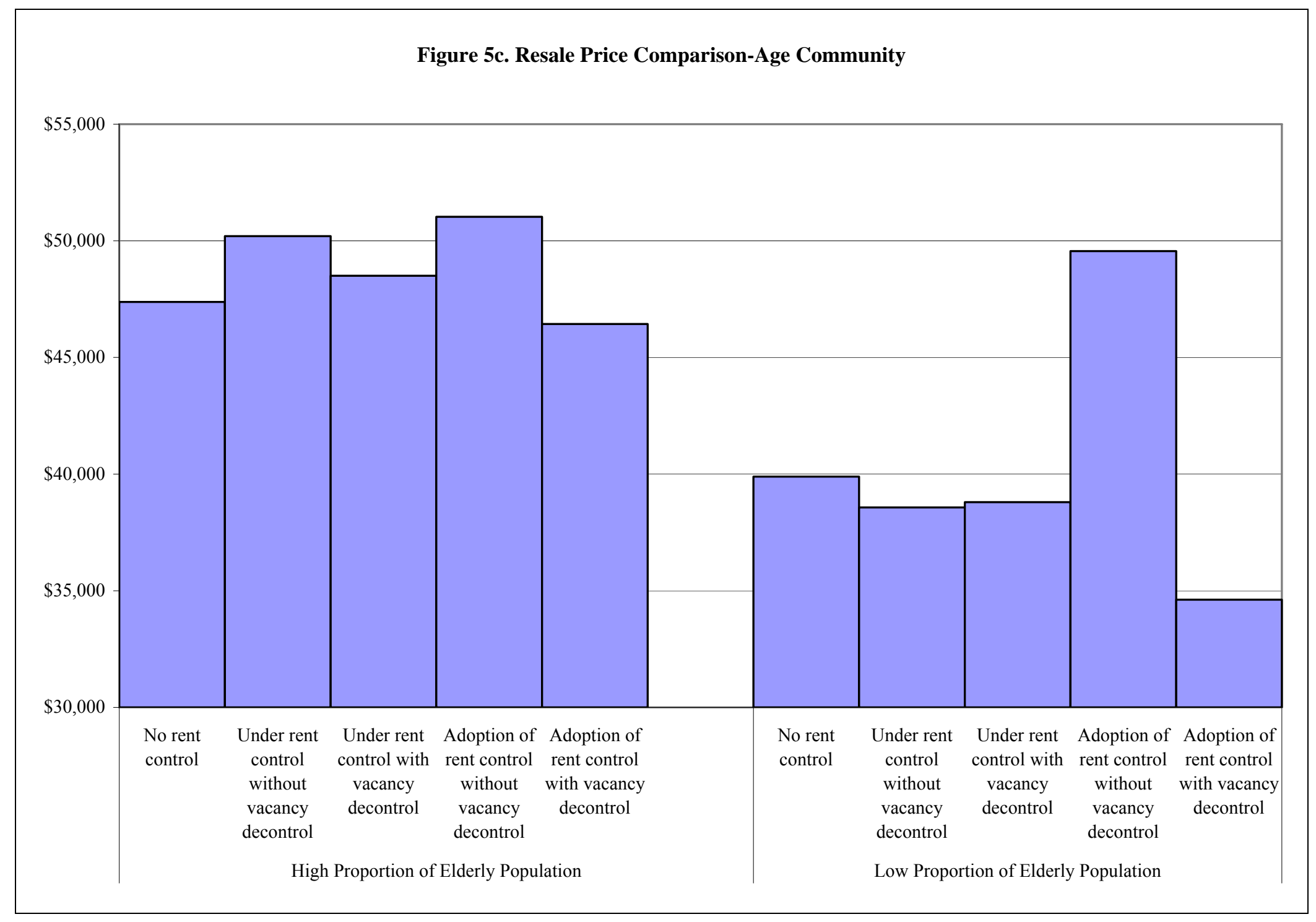




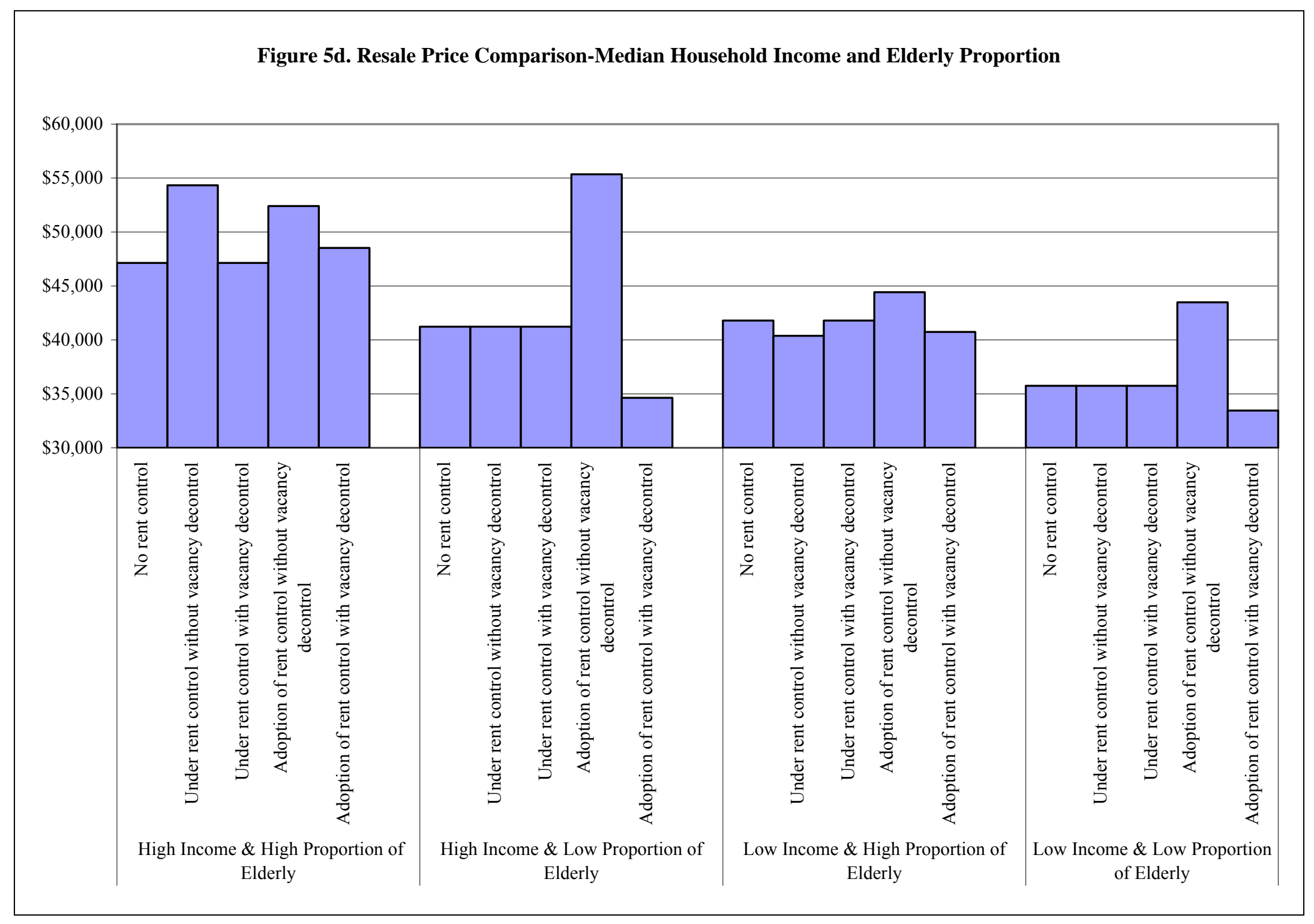

